\title{
LUIZ RASCOVSKI
}

A atuação da Defensoria Pública do Estado de São Paulo na efetivação do direito à educação infantil

Tese de Doutorado

Orientadora: Professora Associada Nina Beatriz Stocco Ranieri

UNIVERSIDADE DE SÃO PAULO

FACULDADE DE DIREITO

SÃO PAULO - SP

2020 



\section{LUIZ RASCOVSKI}

\section{A atuação da Defensoria Pública do Estado de São Paulo na efetivação do direito à educação infantil}

Tese Apresentada a Banca Examinadora do Programa de Pós-Graduação em Direito, da Faculdade de Direito da Universidade de São Paulo, como exigência parcial para obtenção do título de Doutor em Direito, na área de Concentração de Direito do Estado, sob orientação da Professora Associada Nina Beatriz Stocco Ranieri.

UNIVERSIDADE DE SÃO PAULO

FACULDADE DE DIREITO

SÃO PAULO - SP

2020 
Ficha Catalográfica

Faculdade de Direito da Universidade de São Paulo

RASCOVSKI, Luiz

A atuação da Defensoria Pública do Estado de São Paulo na efetivação do direito à educação infantil / Luiz Rascovski / São Paulo: USP/Faculdade de Direito, 2020. 279 fls.

Orientadora: Professora Associada Nina Beatriz Stocco Ranieri

Tese (Doutorado), Universidade de São Paulo, USP, Programa de Pós-Graduação em Direito, Direito do Estado, 2020.

1. Direito do Estado. 2. A atuação da Defensoria Pública do Estado de São Paulo na efetivação do direito à educação infantil. 3. RANIERI, Nina Beatriz Stocco. 


\section{BANCA EXAMINADORA}

Professora Associada Nina Beatriz Stocco Ranieri

(Orientadora)

Professor/a Doutor/a

Professor/a Doutor/a

Professor/a Doutor/a

Professor/a Doutor/a

Professor/a Doutor/a 



\section{AGRADECIMENTOS}

Ao núcleo duro de direitos fundamentais de minha vida: minha esposa Daniela e meus filhos Isabela e Guilherme. Absolutos, essenciais e inegociáveis. Exatamente como aquilo que se sobrepõe no sopesamento de direitos. Assim são eles! Faço para eles e por eles. E neles encontro o apoio, força e paz para seguir adiante.

À minha mãe Janete, que com a partida precoce de meu pai Adolpho, soube mais do que sempre, administrar a vida e entregar seu amor incondicional aos filhos, fazendo de nós pessoas de bem. Ao meu pai, todo agradecimento pelo suor diário derramado para nos dar condições de trilhar os melhores caminhos e oportunidades.

Agradeço, também, minhas irmãs Alessandra e Andreia companheiras e amigas que a vida me deu juntamente com a maturidade de quem começa a entender o que importa na vida e que as tais brigas de infância se transformam em companheirismo, comprometimento, amizade e acima de tudo bem querer.

À Professora Nina Beatriz Stocco Ranieri, tanto por ter me incentivado a enfrentar os implacáveis desafios do trabalho acadêmico consistente na reflexão acerca da instituição da qual faço parte, mas que me creditou a mim o direito dela examinar, confiando que o faria de forma ética e imparcial e, acima de tudo, empolgada com tal escolha. Quanto, igualmente, por ter compreendido os períodos de dificuldade que me forçavam a desviar do nobre caminho acadêmico. Desde o primeiro encontro, por coincidências da vida, criei empatia incomensurável pela pessoa que é e pelo trabalho de fôlego na área educacional que me honrou com vossa orientação. Autora de obras e posicionamentos tão lúcidos e contributivos, representando verdadeira defensora do direito à educação, como forma máxima não só de concretização dos ditames constitucionais, mas como evolução da sociedade.

Aos professores que contribuíram nesta caminhada com a oportunidade de ter cursado disciplinas essenciais para a realização de minha tese e, especialmente, por assegurar espaço privilegiado de pesquisa sobre o direito à educação na Faculdade de Direito da Universidade de São Paulo. 
Aos amigos do GTIEI, cuja batalha conjunta pela educação infantil nos fez criar laços extrajurídicos. Agradeço a todos do grupo, em especial com quem tive oportunidade de aprender ainda mais: Alessandra Gotti, Rubens Naves, Salomão Ximenes, Ester Rizzi, João Paulo Faustinoni e Silva, Ananda Grinkraut e Mariana Kiefer Kruchin.

Ao ex-secretário municipal de educação Cesar Callegari, meu agradecimento ao homem público de bem que é e pela dedicação, mesmo diante dos entraves, pela pasta educacional.

Um último agradecimento ao Dr. Samuel Alves Junior, desembargador aposentado do Tribunal de Justiça do Estado de São Paulo, que compreendeu em toda sua essência o Trabalho do GTIEI e pode - com sua atuação diferenciada, envolvida, entusiasmada e, acima de tudo, corajosa - trazer novos rumos para o direito à educação infantil no município de São Paulo. 
"Um livro, uma caneta, uma criança e um professor podem mudar o mundo".

Malala Yousafzai.

Se este trabalho contribuir, de alguma forma, para que meus filhos tenham um país menos desigual e com melhoria ao acesso à educação, certamente terá atingido seu verdadeiro objetivo. 

RASCOVSKI, Luiz. A atuação da Defensoria Pública do Estado de São Paulo na efetivação do direito à educação infantil. 2020. 279 fls. Doutorado - Faculdade de Direito, Universidade de São Paulo, São Paulo, 2020.

\section{RESUMO}

A Defensoria Pública, ao lado do Ministério Publico, até então instituição exclusiva na promoção dos interesses sociais, ganhou contornos constitucionais de extrema relevância e tratamento diferenciado para a defesa dos interesses dos necessitados. Dentre estes, o direito à educação. Obviamente que sem se dissociar da experiência prática do autor, mas procurando manter distância e imparcialidade suficiente, com afastamento de conatações subjetivas e pessoais, o trabalho promove reflexão crítica acerca da organização institucional da Defensoria Pública na efetivação do direito à educação, mais especificamente do direito à educação infantil.

A tese desenvolve-se sobre tema específico, qual seja, o exame organizacional da Defensoria Pública do Estado de São Paulo enquanto instituição incumbida da efetivação do direito à educação infantil. Quer dizer, o assunto cinge-se na problemática da ausência de vagas em creches e pré-escola para salvaguardar e acolher as crianças da faixa etária da educação infantil e o questionamento da organização institucional para enfrentamento desta dificuldade. Dentro desta problematizada situação, o trabalho já parte para um exame da organização institucional da Defensoria, sob o ângulo de três perspectivas principais de atuação: pela via das ações individuais, pela via das ações coletivas e pela via das soluções consensuais (englobando nesta última os processos dialógicos). A verificação de cada uma destas formas de atuação almeja traçar o resultado alcançado por cada método, checando justamente se a Defensoria encontra-se institucionalmente organizada em cada uma dessas searas de atuação utilizado pela instituição.

Por fim, com este diagnóstico, serão explicitados alguns entraves que justamente impedem alcançar uma maior eficiência na efetivação do direito à educação. A análise destes entraves servirá para evidenciar os gargalos da atuação e, subsequentemente, 
apresentar algumas propostas para o aperfeiçoamento institucional da Defensoria no intuito de colaborar para a consolidação do direito à educação.

Palavras-chave: Defensoria Pública. Direito à educação infantil. Organização institucional. Judicialização. Litigância Estratégica. 
RASCOVSKI, Luiz. The performance of the Public Defender's Office of the State of São Paulo in enforcing the right to early childhood education. 2020. 279 fls. Doctorate Faculty of Law, University Of São Paulo, São Paulo, 2020.

\begin{abstract}
The Public Defender's Office, next to the Public Ministry, so far unique institution in the promotion of social interests, won constitutional contours of extreme relevance and differential treatment to the interests of the poor and needy. Among these, the right to education. Obviously without decoupling of the author's practical experience, but looking for keep distance and impartiality enough, with removal of subjective and personal connotations, the work promotes critical reflection about the institutional organization of Public Defender's Office in implementation of the right to education, more specifically the right to education for children.
\end{abstract}

The thesis is developed on specific subject, namely, the exam of the Public Defender's Office's of the State of São Paulo organization as an institution responsible for the implementation of the right to education for children. I mean, the subject is limited in the absence of places in day care and preschool to safeguard and welcome children of age range of early childhood education and the questioning of the institutional organization for confronting this difficulty. In this critical situation, the work piece to an examination of the institutional organization of Public Defender's Office under the angle of three main perspectives: the path of individual actions, by way of collective action and the path of the consensual solutions (including in this latest dialogic procedures). The verification of each of these forms of action aims to trace the result achieved by each method, check precisely if the Public Defender's Office is institutionally organized in each of these fields of action used by the institution.

Finally, with this diagnosis will be explained some obstacles that prevent achieving greater efficiency in the implementation of the right to education. The analysis of these barriers will serve to highlight performance bottlenecks and, subsequently, submit some proposals for improving institutional Public Defender's Office in the intent to collaborate for the consolidation of the right to education. 
Keywords: Public Defender's Office. Right to childhood education. Institutional organization. Judicialization. Strategic Litigation. 
RASCOVSKI, Luiz. El desempeño de la Oficina del Defensor Público del Estado de São Paulo en la aplicación del derecho a la educación de la primera infancia. 2020. 279 fls. Doctorado - Facultad de Derecho, Universidad de São Paulo, São Paulo.

\section{RESUMEN}

La Oficina del Defensor Público, junto con el Ministerio Público, hasta entonces una institución exclusiva en la promoción de los intereses sociales, ganó contornos constitucionales de extrema relevancia y trato diferenciado para defender los intereses de los necesitados. Entre estos, el derecho a la educación. Obviamente, sin disociarse de la experiencia práctica del autor, pero buscando mantener una distancia e imparcialidad suficientes, lejos del contacto subjetivo y personal, el trabajo promueve la reflexión crítica sobre la organización institucional de la Oficina del Defensor Público en la realización del derecho a la educación, específicamente el derecho a la educación de la primera infancia.

La tesis se desarrolla sobre un tema específico, a saber, el examen organizacional de la Oficina del Defensor Público del Estado de São Paulo como una institución encargada de hacer cumplir el derecho a la educación de la primera infancia. Es decir, el tema se limita al problema de la falta de vacantes en jardines de infantes y preescolares para proteger y acoger a los niños del grupo de edad de jardín de infantes y el cuestionamiento de la organización institucional para enfrentar esta dificultad. Dentro de esta situación problematizada, el trabajo ya va a un examen de la organización institucional de la Defensoria, desde el ángulo de tres perspectivas principales de acción: a través de acciones individuales, a través de acciones colectivas y a través de soluciones consensuadas (incluyendo en este último el procesos dialógicos). La verificación de cada una de estas formas de acción tiene como objetivo rastrear el resultado logrado por cada método, verificando con precisión si la Oficina del Defensor está institucionalmente organizada en cada uno de estos campos de acción utilizados por la institución.

Finalmente, con este diagnóstico, se harán explícitos algunos obstáculos que justifiquen lograr una mayor eficiencia en la realización del derecho a la educación. El análisis de estas barreras servirá para resaltar los cuellos de botella de la acción y, 
posteriormente, presentar algunas propuestas para la mejora institucional de la Defensoría con el fin de contribuir a la consolidación del derecho a la educación.

Palabras clave: Oficina del Defensor Público. Derecho a la educación infantil. Organización institucional. Judicialización. Litigio Estratégico. 


\section{SUMÁRIO}

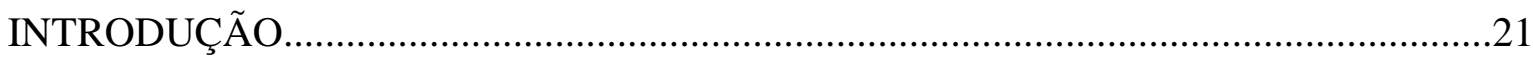

CAPÍTULO 1 - EDUCAÇÃO INFANTIL - DA NORMATIZAÇÃO À

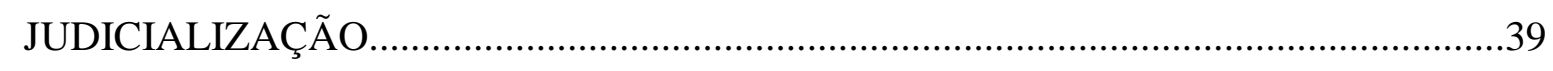

1.1. Marco normativo constitucional - A Constituição Federal de 1988.........................39

1.1.1. A Emenda Constitucional 14/96 .................................................................44

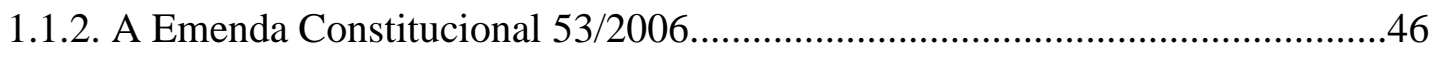

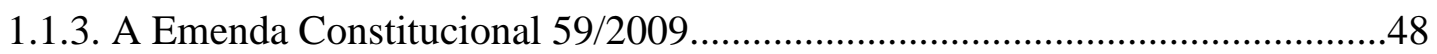

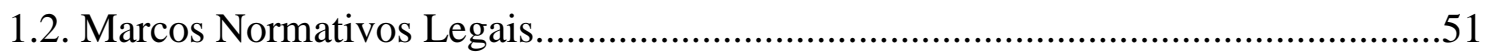

1.2.1. Lei de Diretrizes e Bases da Educação Nacional............................................52

1.2.2. Estatuto da Criança e do adolescente - ECA..................................................54

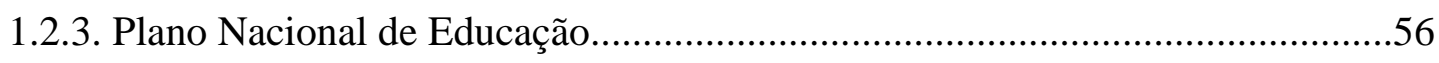

1.3. A educação Infantil e o Poder Público Municipal como ente prioritário.................62

1.4. O planejamento da política através do Programa de Metas do Município...............66

1.5. A percepção ao longo dos anos de que as normas não concretizavam o direito social à educação infantil - déficit de atendimento

1.6. Judiciário como nova arena para efetivação da política pública educacional (instado a participar do controle da política).

1.6.1. O Supremo Tribunal Federal e a mudança de perspectiva - direito à educação visto como direito público subjetivo exigível e não mera norma programática..........75

1.6.2. Ministério Público como primeiro protagonista na atuação judicial.................81

1.6.2.1. A estratégia das ações coletivas (ações civis públicas ministeriais)..........83

1.6.3. A ONG Ação Educativa (1994) e outras instituições......................................89

1.6.3.1. A estratégia das ações coletivas das ONGs............................................94

1.6.4. A Defensoria Pública como nova protagonista da litigância da educação infantil .98

CAPÍTULO 2 - ASPECTOS INSTITUCIONAIS DA DEFENSORIA EM RELAÇÃO À ATUAÇÃO DE SEUS MEMBROS EM AÇÕES INDIVIDUAIS. 105

2.1. Panorama Geral: ingresso na carreira, quadro de defensores e unidades, regras para definição de cargos e atribuições, composição, expansão de acordo com a emenda constitucional 80/2014. 
2.2. Defensores com atribuição específica atuantes na infância e juventude (titular, substituto, itinerante). Consequências da rotatividade. 113

2.3. Desenho organizacional institucional para atuação nas ações individuais com matéria da educação infantil: triagem $X$ polos $X$ unidades - modelo capital e interior

2.4. Criação de atendimento expresso para ações de pedidos de vagas em creche enxurrada de ações judiciais individuais (litigância massificada).

2.5. Saturação do modelo e o efeito "fura-fila" com mudança na ordem cronológica.

2.6. Discussão: possibilidade de suspensão do ajuizamento de ações individuais (obrigatoriedade de agir) em cotejo com a promoção do acesso à justiça

2.7. Locais em que não existe atuação direta da Defensoria Pública.

2.8. Inexistência de atuação estrategicamente organizada e concatenada (procedimentos padronizados de orientação) de atuação na área da educação infantil X independência funcional.

CAPÍTULO 3 - ASPECTOS INSTITUCIONAIS DA DEFENSORIA EM RELAÇÃO À ATUAÇÃO DE SEUS MEMBROS NAS AÇÕES COLETIVAS.

3.1. Tutela coletiva por meio de atuação individual - legitimidade para ajuizamento de ação civil pública.

3.1.1. Indefinição específica do legitimado versus subjetivismo de atuação.

3.2. Deliberação CSDP $n^{\circ} 139$ - Defensorias de tutela coletiva.

3.3. Tutela Coletiva por meio do Núcleo Especializado da Infância e Juventude

3.4. Ausência de planejamento estratégico ou política definida para enfrentamento institucional dos problemas na educação infantil.

CAPÍTULO 4 - ASPECTOS INSTITUCIONAIS DA DEFENSORIA FRENTE À POSSIBILIDADE DE ATUAÇÃO EM AÇÕES JUDICIAIS OU EXTRAJUDICIAIS DIALÓGICAS COM CONSTRUÇÃO DE SOLUÇÕES CONSENSUAIS ESPECIALMENTE EM CONJUNTO COM OUTRAS INSTITUIÇÕES .......................205

4.1. Tendência atual de construções dialógicas relacionados à implementação de políticas públicas notadamente na área de direitos fundamentais. .205

4.2. A organização institucional da Defensoria para atuação em acordos interinstitucionais- indefinição de legitimado e do procedimento. .214 
4.3. A experiência do GTIEI: Atuação inovadora no "leading case" do Grupo Interinstitucional de Educação Infantil - GTIEI, na busca de solução para concretização da política pública educacional no Município de São Paulo.........................................222

4.3.1. A audiência pública e as rodadas de negociações........................................229

4.3.2. A decisão paradigmática do Tribunal de Justiça do Estado de São Paulo......234

4.3.3. A criação do Comitê de Monitoramento..........................................................236

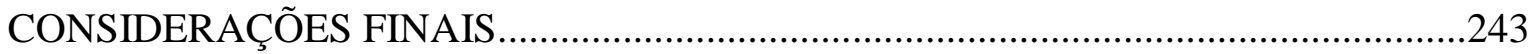

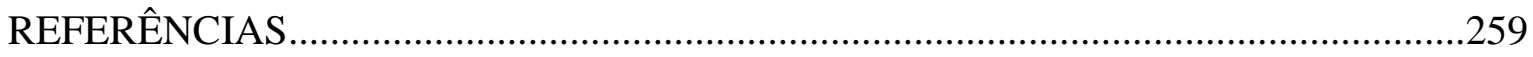





\section{INTRODUÇÃO}

A presente tese investiga a atuação da Defensoria Pública ${ }^{1}$ do Estado de São Paulo na concretização dos direitos fundamentais ${ }^{2}$, notadamente na efetivação do direito à educação ${ }^{3}$ infantil. Na verdade, o desejo deste estudo surgiu da práxis. Sua origem advém, especialmente, de nossa atuação profissional como Defensor Público do Estado de São Paulo, ingressante na carreira no ano de 2007, exercendo atribuições em Órgão de execução, cujo encargo consiste (dentre outros) na promoção e defesa do direito à educação.

Desde a criação da Defensoria Pública do Estado de São Paulo, no ano de 2006, notou-se que um dos maiores desafios da instituição consiste em garantir o acesso às vagas em creches e pré-escolas para crianças de zero a cinco anos. No município de São Paulo a situação é alarmante. Porém, guardadas as proporções, o problema se alastra por diversas comarcas do Estado e a solução definitiva não parece próxima. Ainda que aparentemente problema do Poder Executivo, a impotência da Defensoria em não obter êxito na efetivação do direito educacional infantil vem gerando uma série de debates internos, com discussão sobre a validade de sua atuação. Portanto, o tema da pesquisa cinge-se no questionamento da organização institucional da Defensoria Pública para a concretização do acesso e efetivação do direito à educação infantil (creches e pré-escolas).

Esse crescente desejo de tratar do assunto foi alimentado pelas agonias experimentadas na rotina diária institucional e pela humilde ambição de colaborar para alcançar genuinamente a declaração constitucional de que a educação é um direito de todos, de forma gratuita, com acesso universal, sem se descurar do padrão de qualidade ${ }^{4-5}$.

\footnotetext{
${ }^{1}$ No dizer de Rogério Lauria Tucci: “a Defensoria Pública é instituição tipicamente social, de "advogado do povo", que servirá para a necessária e prévia orientação jurídica, bem como para a defesa, pré-processual e processual, em todos os graus de jurisdição, das pessoas desprovidas de recursos financeiros para o respectivo custeio". (TUCCI, Rogério Lauria. Direitos e Garantias individuais no processo penal brasileiro. São Paulo: Saraiva, 1993, p. 104).

${ }^{2}$ Desde a promulgação da Carta Magna de 1988, a Defensoria Pública - como instituição a serviço dos necessitados, especialmente na concretização dos direitos fundamentais - ganhou status constitucional.

${ }^{3}$ A palavra 'educação' vem do latim “educere”: que significa desenvolver, extrair, ministrar o necessário ao crescimento da personalidade do indivíduo, desde o nascimento até a morte.

${ }^{4}$ A tese concentra seu questionamento na organização institucional da Defensoria no tocante à efetivação do direito à educação infantil. A ênfase do trabalho consiste na questão do acesso à educação. Quer dizer, muitos dos dados e exemplos ao longo do trabalho referem-se aos empecilhos ligados ao déficit de vagas, ao problema de acesso. Entretanto, não se pode entender o amplo direito à educação tão somente com o acesso, porquanto este se torna insuficiente e principalmente deficiente se não estiver aliado com a qualidade da
} 
Assim, as angústias enfrentadas para fazer valer o texto constitucional e a vontade de emplacar mudanças em razão dos fracassos sentidos na lida cotidiana consistiram em motivação para uma análise concatenada, com fôlego de estudo acadêmico. Tudo com o objetivo de identificar os entraves e apresentar prováveis medidas para o aperfeiçoamento da atuação institucional e organização da Defensoria Pública, que se refere à sua capacidade de enfrentar o desafio de promover o direito à educação infantil.

Não seria leal, tampouco ético, não apresentar logo no início deste trabalho a condição pessoal do autor, como Defensor, local de onde parte a observação e ponto de sua percepção do objeto de pesquisa. Contudo, entendemos que esta condição não prejudica o desenvolvimento do trabalho na medida em que se busca distanciar do caráter subjetivo. Porém, sem deixar de realizar uma análise crítica do arranjo institucional da Defensoria Pública na efetivação do direito à educação.

A pergunta central que esta tese busca responder pode ser assim apresentada: a Defensoria Pública do Estado de São Paulo, na seara da concretização do direito à educação infantil, está institucionalmente organizada para desincumbir-se com validade e eficiência dos deveres que lhe foram constitucionalmente impostos?

educação. Aliás, a própria Constituição Federal em diversos dispositivos deixa transparecer a importância da qualidade na questão da educação. Dentre os artigos podemos citar: a) art. 206, inciso VII - que trata da garantia do padrão de qualidade; b) art. 210 - que em seu caput aponta a fixação de conteúdos mínimos para a formação de base comum; c) art. 214, III - consistente na promoção da melhoria do ensino no Plano Nacional de Educação. Não podemos falar na questão da qualidade da educação sem citar Salomão Barros Ximenes, integrante do GTIEI e que ao longo das reuniões e tratativas com o Executivo e mesmo na questão acadêmica é um estudioso preocupado com o problema da qualidade. Ximenes, com amparo nos ditames constitucionais e nos tratados internacionais de direitos humanos, enumera sete dimensões quanto ao conteúdo jurídico do direito à qualidade do ensino: estudantes, ambiente escolar, condições de infraestrutura e insumos básicos, conteúdos, processos educacionais relevantes, resultados e financiamento público (2014, p. 392). E assim finaliza: "O direito à qualidade na educação básica é entendido [...] como o conjunto de condições de infraestrutura, humanas e de insumos que permitem o desenvolvimento de processos educacionais relevantes e adaptados, assegurados gratuita e universalmente pelo Estado, visando garantir a todos a aprendizagem de conteúdos, habilidade e competências necessárias à realização dos direitos humanos na educação e através da educação. $\mathrm{O}$ objetivo do direito à educação é alcançar a igualdade de base em termos de sucesso escolar, com respeito à diversidade. Nesse caminho, ambiente escolar, conteúdos e processos educacionais são partes estruturantes e inalienáveis do direito à qualidade, devem assim ser protegidos e realizados. Ao direito infraconstitucional cabe delimitar e articular cada um desses aspectos, o que deve ser feito tanto através de normas jurídicas gerais como do desenho jurídico-institucional das políticas públicas (XIMENES, Salomão Barros. Direito à qualidade na educação infantil: teoria e crítica. São Paulo: Quartier Latin do Brasil, 2014 p. 402-403).

${ }^{5}$ Alessandra Gotti, em seu artigo "Um Retrato da Judicialização da Educação Básica no Brasil”, alerta que "ë tímida a atuação por uma Educação Básica pautada por parâmetros de qualidade e, em especial, que questione os eventuais retrocessos e estagnações apontados pelos exames nacionais de avaliação do sistema”. GOTTI, Alessandra. Um retrato da judicialização da educação Básica no Brasil. In: "Reflexões sobre Justiça e Educação". Organização Todos pela Educação. São Paulo: Editora Moderna, 2017, p. 45. 
Reforça-se que esta hipótese (qual seja, "se a atuação da Defensoria Pública do Estado de São Paulo na efetivação do direito social à educação infantil, por meio de seu desenho institucional e organização prática, tem sido eficiente") não foi elaborada por observador externo e hipoteticamente neutro. Mas, por membro da instituição, integrante de carreira que, em sua experiência habitual, paulatinamente passou a notar que a Defensoria - como instituição nova - buscava uma identidade própria e tentava romper com as amarras da antiga $\mathrm{PAJ}^{6}$ - Procuradoria de Assistência Judiciária ${ }^{7-8}$. No entanto,

\footnotetext{
${ }^{6}$ Schubsky faz uma cronologia da Assistência Jurídica e do surgimento da PAJ. Narra o autor que "A origem da assistência jurídica remete à Lei Imperial no 261 , de 1841 , que previa o pagamento de metade das custas judiciais pela Câmara Municipal, no caso de processo contra réus pobres. A lei foi regulada em 1842 pelo Regulamento $\mathrm{n}^{\circ} 120$, que conferia a mesma isenção aos réus criminais pobres, condenados judicialmente. Em 1919, foi criada a Assistência Jurídica Acadêmica, posteriormente chamada Departamento Jurídico XI de Agosto, ligado ao Centro Acadêmico da Faculdade de Direito da Universidade de São Paulo (USP). No ano seguinte, a Lei Estadual n 1.763 organizou a assistência judiciária no Estado. O Artigo $1^{\circ}$ da lei dizia que "as pessoas desprovidas de meios pecuniários para a defesa judicial de seus direitos são admitidas a impetrar o benefício da Assistência Judicial". Tal assistência consistia em isenção de pagamento de custas, selos estaduais, taxas e emolumentos, assim como a designação de um patrono (advogado) ex officio. Em 1931, foi criado o Departamento de Trabalho Agrícola, que tinha como uma de suas funções assistir judicialmente trabalhadoras e trabalhadores agrícolas. O Departamento de Assistência Social do Estado foi criado em 1935, contendo uma divisão chamada Consultório Jurídico de Serviço Social, que prestava assistência jurídica aos que precisassem de proteção social, como menores de idade, pobres etc. Seus serviços incluíam isenção de pagamento de custas, taxas e emolumentos de atos processuais e assistência judiciária. Em 1947, por meio do Decreto-Lei Estadual $\mathrm{n}^{\circ}$ 17.274, o Departamento de Serviço Social passa a se chamar Serviço Social do Estado. No mesmo ano, o Decreto-Lei Estadual no 17.330 estabeleceu o Departamento Jurídico do Estado, que congregou os órgãos jurídicos que tratavam da advocacia pública em São Paulo, e a Procuradoria do Serviço Social - como foi depois chamado o Consultório Jurídico de Serviço Social - foi novamente rebatizada, tornando-se a Procuradoria de Assistência Judiciária (PAJ). A PAJ passou em 1948 a ter dotação orçamentária do Departamento Jurídico do Estado, ligado à Secretaria da Justiça e Negócios do Interior. Os serviços incluíam assistência judicial e extrajudicial a pessoas pobres, sem encargos de custas, selos e honorários profissionais, e orientação jurídica sobre direitos e deveres. Em 1984, a Lei Estadual no 4.476 criou o Fundo de Assistência Judiciária da PGE. O Decreto Estadual no 23.703/85 regulamentou a lei, prevendo fontes de receita e permitindo a celebração de convênios para prestação da assistência judiciária. Para garantir o serviço à população, e considerando o crescimento da demanda, foi firmado convênio entre a Secretaria de Estado da Justiça, a PGE e a Seção de São Paulo da Ordem dos Advogados do Brasil $(\mathrm{OAB} / \mathrm{SP})$. Por meio do convênio, advogados inscritos em todo o Estado passaram a ser nomeados para prestar o serviço à população carente em locais onde não houvesse procuradores ou houvesse em quantidade insuficiente. Foi criada uma tabela de honorários advocatícios e as despesas passaram a ser custeadas pelo FAJ. O convênio de assistência judiciária existe até hoje e é mantido entre a OAB/SP e a Defensoria Pública paulista. Os profissionais inscritos no convênio mantêm o serviço de assistência judiciária nos locais do Estado em que ainda não há Defensoria Pública ou onde não há defensores públicos em quantidade suficiente" Schubsky, Cássio (2008). Advocacia pública: apontamentos sobre a história da Procuradoria Geral do Estado de São Paulo $1^{a}$ ed. São Paulo: Imprensa Oficial do Estado de São Paulo. p. 98-110.

7 "Anteriormente à criação da Defensoria Pública do Estado de São Paulo (DPE/SP), o acesso à justiça das pessoas em condição de vulnerabilidade social estava relacionado ao Poder Executivo por meio da Procuradoria de Assistência Judiciária (PAJ). A PAJ acumulava as funções de defesa e orientação jurídica ao Governo do Estado e prestação de assistência judiciária aos necessitados. A partir da Constituição do Estado de São Paulo de 1967, a Procuradoria-Geral do Estado obteve a qualidade de instituição permanente reconhecida como essencial à Administração Pública, sendo disciplinada em 1986 pela Lei Complementar n. ${ }^{\circ}$ 478 (Lei Orgânica da Procuradoria-Geral do Estado). Esse é um órgão vinculado diretamente ao Governador do Estado, responsável pela defesa do Estado, da Administração direta e autarquias, por assessorar e prestar consultoria ao Poder Executivo. Antes da criação da Defensoria Pública do Estado de São Paulo, a organização interna da Procuradoria-Geral do Estado estava dividida em três campos de atuação por meio dos órgãos de execução: o Contencioso Geral, cujo papel central se constitui em representar a Fazenda do Estado em Juízo; a Consultoria, direcionada à emissão de pareceres de assunto de interesse da Administração
} 
ainda repetia (como continua repetindo) rotinas de atuação da instituição que sucedeu. Não que isso fosse obrigatoriamente ruim, mas evidencia, no mínimo, uma continuidade mecanizada de trabalho, sem observância de métodos próprios.

Para robustecer este quadro de incertezas, a instituição recém-criada não dispunha de regras e modelos de atuação estrategicamente já bem definidos e delineados. A todo o momento - quando de seus passos inaugurais - seu Órgão de deliberação era instado a interpretar aquilo que suas normas institucionais queriam dizer e, no seu silêncio, a editá-las por meio de órgãos internos legitimados a legislar. As interpretações e edições muitas vezes tomaram caminhos tortuosos ou não deixavam claros os rumos decididos, refletindo na atuação institucional. Ladeado a este contexto existia a situação de dinamicidade de uma instituição em criação e constante mutação, com poucos defensores em seus quadros, assoberbados de tanto trabalho, que mal conseguiam acompanhar tais edições normativas internas e sofriam com a carência de diretrizes institucionais claras e padronizadas, no sentido de promoção de uma performance estratégica e concatenada da instituição. Dominava, como dito, uma atuação repetitiva, isolada e sem compartilhar métodos e resultados.

Fato é que a Defensoria nasceu, cresceu e avançou rapidamente, de maneira aguerrida, mas de certa forma desordenada, presa a estruturas e formas de atuação profundamente marcadas por sua origem na tutela eminentemente de cunho individual de direitos dos hipossuficientes, embora legitimada a atuar de forma coletiva e global. Tateava sua nova identidade, esquadrinhando-a muitas vezes por tentativa e erro, mas com dificuldade em encontrar princípios norteadores, estrutura organizacional, procedimentos e modos de agir apropriados notadamente à intervenção em políticas públicas educacionais.

\footnotetext{
Pública; e a Assistência Judiciária, espaço para a assistência judiciária aos necessitados”. Cajuella, Fayola Sant' Anna. O acesso à justiça e o direito à educação infantil: um estudo sobre a atuação da Defensoria Pública do Estado de São Paulo / Fayola Sant'Anna Cajuella. 2016, p. 34, dissertação de mestrado, FGV.

8 A assistência judiciária dirigida aos necessitados em São Paulo foi prestada pela Procuradoria de Assistência Judiciária (PAJ), que era Órgão de execução da Procuradoria-Geral do Estado (PGE) de 1947 a 2006. "Até o início do funcionamento da Defensoria Pública em 2006, havia 351 procuradores do Estado atuando na PAJ distribuídos em apenas 21 das mais de 300 comarcas do Estado" (SOARES, Thais. A atuação da Defensoria Pública do Estado de São Paulo: a construção de um modelo inovador. In: HADDAD, Eneida Gonçalves de Macedo. A Defensoria Pública do Estado de São Paulo: por um cesso democrático à Justiça. São Paulo: Letras Jurídicas, 2011. p. 215).
} 
Portanto, de se notar que a formulação da questão central, assim como a hipótese inicial de resposta nos aparece - ao menos - parcialmente negativa. Do mesmo modo, o interesse em realizar averiguação cautelosa e que possa dar respostas mais convincentes à indagação central e aos questionamentos paralelos que surgirão ladeados ao problema central não é simplesmente teórico, mas tem por desígnio esclarecer e assinalar falhas práticas no atual padrão de organização e atuação institucional da Defensoria Pública. Tudo no anseio de colaborar com a construção de alternativas e medidas de aprimoramento, que possam confiar à instituição melhores condições de alcançar seu importante papel na concretização do direito à educação infantil, tal como anunciado na Carta Maior.

A intenção do trabalho não consiste numa simples fabricação de um fluxograma prático de reforma institucional sem problematizar aspectos teóricos fundamentais, como o papel e o lugar da Defensoria Pública no Estado Democrático de Direito, a relação da instituição com a consecução da política pública ${ }^{9}$, seu comprometimento com a sociedade civil, destinatária direta de seus serviços, bem como a correlação de tais questões com o desenho e as formas de ação da instituição. Todavia, procurou-se adotar o acautelamento permanente para estabelecer o distanciamento necessário para a produção de trabalho que não se compendiasse ao mero relato de percepções pessoais, de narrativa das dificuldades ou soluções adotadas em casos concretos.

\footnotetext{
${ }^{9}$ Na evolução do conceito de política pública, deve-se à Ronald Dworkin as formulações científicas básicas delineadoras do sentido adequado da policy, que para este autor se associa à ideia de diretrizes da Administração Pública, ou seja, de metas, objetivos sociais que exigem um programa de ação a ser desenvolvido e realizado pelo Estado providência, atrelado à ideia do Estado de Bem-Estar Social (Welfare State). De se entender, também, que, conforme as lições de Fábio Comparato, a política pública não se resume a norma e nem a ato jurídico, que possuem natureza heterogênea e se submetem a regime jurídico próprio, mas os engloba como seus componentes, por ser a política, antes de tudo, uma "atividade, isto é, um conjunto organizado de normas e atos tendentes à realização de um objetivo determinado" (COMPARATO, 1997, p. 44 e 45). Pensando nas políticas públicas como o conjunto de planos e programas de ação governamental voltado à intervenção no domínio social, por meio dos quais são traçadas as diretrizes e metas a serem fomentadas pelo Estado, sobretudo na implementação dos objetivos e direitos fundamentais dispostos na Constituição, é que Maria Paula Dallari Bucci definiu políticas públicas como sendo "programas de ação governamental visando a coordenar os meios à disposição do Estado e as atividades privadas, para a realização de objetivos socialmente relevantes e politicamente determinados" (BUCCI, 2002, p. 241).

No mesmo sentido, destaca Eros Grau que: "A expressão política pública designa atuação do Estado, desde a pressuposição de uma bem demarcada separação entre Estado e sociedade" (GRAU, 2005, p. 25), o que terminou por influenciar também o significado dado por Américo Bedê ao conceito de políticas públicas, quando afirmou que "pretende significar um conjunto ou uma medida isolada praticada pelo Estado com o desiderato de dar efetividade aos direitos fundamentais ou ao Estado Democrático de Direito" (FREIRE JUNIOR, 2005, p. 47).
} 
Por óbvio que a condição de Defensor Público do Estado proporcionou importante intercâmbio com defensores, juízes e promotores, além de operadores do direito envolvidos na causa da educação infantil, fomentando a troca de informações e experiências. Vale destacar, ainda, o rico contato com secretarias e diretorias de ensino, bem como professores e gestores da educação, além da coletividade em geral, formada especialmente por pais e mães de alunos. $\mathrm{O}$ contato e envolvimento com a rede completa de envolvidos com a temática da educação infantil nos credencia a conhecer todos os lados da moeda e compreender melhor os anseios e dificuldades de cada ator envolvido.

Agora, partindo da constatação prática de fragilidades na maneira de organização e no agir institucional, a proposta é verificar em que medida o atual desenho atende às demandas constitucionalmente balizadas e confere à instituição as condições de, contribuir eficientemente para a concretização do direito à educação, integrante dos objetivos fundamentais da República Federativa do Brasil. Em outras palavras, investigar se referido desenho cria obstáculos ou atalhos para que a instituição possa atingir seu mister de concretização do direito à educação. Averiguar, ao mesmo tempo, se o modelo organizacional institucional oferecido aos defensores impede que sua atuação não seja apenas voluntarista, desarticulada, demandista e fundada em independência funcional rasteira que se confunda, portanto, com puro subjetivismo.

Importante frisar, neste momento introdutório, que a pesquisa não visa ao exame individualizado da atuação dos membros da Defensoria. Quer dizer, não se objetiva descrever boas práticas ou, ao contrário, apontar condutas eventualmente desviada deste ou daquele Defensor. O objeto consiste na verificação da Defensoria enquanto instituição ${ }^{10-11}$,

\footnotetext{
${ }^{10}$ Cumpre-nos assinalar que o conceito de instituição utilizado neste trabalho levou em consideração a conhecida definição do Professor de direito em Toulouse (1883-1929) e tido como o criador do institucionalismo Maurice Hauriou, para quem: "Uma instituição é uma ideia de obra ou de empresa que se realiza e dura juridicamente num meio social; para a realização dessa ideia, organiza-se um poder que lhe confere órgãos; por outro lado, entre os membros do grupo social interessado na realização da ideia, produzem-se manifestações de comunhão dirigidas pelos órgãos do poder e reguladas por procedimento". Hauriou admite a figura da instituição como fonte do direito e não o próprio direito. As instituições são apresentadas como a categoria da duração, da continuidade e do real. Os elementos da teoria institucional de Hauriou são 3 a) a idéia da obra a realizar em um grupo social; b) o poder organizado posto a serviço dessa idéia para sua realização; c) as manifestações de comunhão que se produzem no grupo social a respeito da idéia e de sua realização. HAURIOU, Maurice. Teoria da Instituição e da Fundação: ensaio de vitalismo social. Porto Alegre: Sergio Antonio Fabris Ed., 2009. No mesmo sentido de Hauriou e seguindo-o João Paulo Faustinoni e Silva empregou em sua tese de mestrado o seguinte conceito: "Instituição, como temos
} 
isto é, dos aspectos institucionais e de como estes refletem na atuação de seus membros e acabam por ter impacto final nas políticas educacionais. Assim, o escopo consiste na análise de como se desenha a organização institucional da Defensoria, para a obtenção de sua missão educacional, não se debruçando de forma geral e alargada sobre o aspecto formal do conjunto de normas que delineiam a instituição.

No entanto, para apresentar respostas à hipótese central da tese, assim como para preparar propostas que efetivamente contribuam para o aprimoramento da instituição na concretização do direito fundamental à educação infantil, necessário o exame de parte da legislação pertinente, em especial sobre educação e sobre aspectos institucionais da Defensoria Pública. Por isso, foram examinadas a Lei Complementar 80 de 1994 (com nova redação dada pela Lei complementar 132/2009) que organiza a Defensoria Pública da União e traça normas gerais para organização das defensorias estaduais; a Lei Complementar 988/2006 que organiza a Defensoria Pública do Estado de São Paulo; algumas Deliberações do Conselho Superior da Defensoria Pública e atos normativos do Defensor Público-Geral no tocante ao tema estudado; algumas propostas relacionadas à educação infantil que foram objeto de discussão e aprovação nas Conferências e Préconferencias da Defensoria Pública de São Paulo, bem como os relatórios de monitoramento dos ciclos de pré-conferências; as teses institucionais da Defensoria Pública ligadas à educação infantil; as normativas do NEIJ - Núcleo da Infância e Juventude da Defensoria Pública do Estado de São Paulo. Ademais, os canais de contato garantidos por meio da lei de acesso à informação foram acionados para levantamento de outras informações relevantes.

sustentado, é organização que condiciona e estimula a ação coletiva de indivíduos em torno de propósitos, de ideia diretriz a ser realizada."

$11 \mathrm{O}$ estudo de instituições é demasiadamente complexo porque envolve uma série de questões. Quando Ostrom foi convidado para escrever sobre a teoria do Institutional Rational Choice resolveu focar mais na analise e desenvolvimento institucional (IAD) do enquadramento teórico. O autor apresenta uma lista daquilo que considera as dificuldades chaves que envolvem o estudo de instituições: $O$ termo instituição refere-se a muitos diferentes tipos de entidades, com múltiplas definições; Instituições nelas mesmas são invisíveis, sendo difícil de identificá-las e mensurá-las; Para desenvolver uma aproximação coerente para estudar os diversos tipos de arranjos institucionais faz se necessárias múltiplas entradas de diversas disciplinas; Com isso múltiplas linguagens são utilizadas através das disciplinas; Estudos institucionais requer múltiplos níveis de análises; A cada nível de análise, combinação de regras e comunidade de indivíduos são combinados numa configuração de relacionamentos. (Elinor OSTROM. "Institutional Rational Choice: An Assessment of the Institutional Analysis and Development Framework", Cornell Law Review, vol. 95, article 15, Issue 4 may 2010). 
Além disso, se revela imprescindível a análise - mesmo que não exaustiva e de forma analítica - de dados estatísticos ligados a demandas judiciais da educação infantil. Vale registrar aqui, que o cerne do trabalho não envolvia o exame meticuloso de dados de processos, como muitos trabalhos que assim já o fizeram com ótima contribuição sobre a atuação do Tribunal de Justiça em resposta a tais demandas. Mas, inevitável deixar de apresentar em muitas passagens a sobrecarga - em números - de demandas perseguindo vagas em creche pela via judicial, justamente para demonstrar a organização institucional no que se refere à atuação por meio de ações.

Neste aspecto, vale registrar que existem importantes estudos ${ }^{12}$ analisando a atuação do Poder Judiciário, sua capacidade de julgar, o conteúdo de suas decisões, bem como da atuação do Ministério Público, relacionados à atuação destas instituições no trato e efetivação do direito à educação. Assim, parece-nos relevante debruçar sobre a atuação da Defensoria, em especial de seus Órgãos de atuação voltados para a defesa do direito à educação. Até porque, pouco se sabe acerca da atuação da Defensoria, neste caso específico, instituição que leva a grande parte da demanda até o Judiciário e que poderia ao menos em tese - adotar caminhos diversos daqueles cujas respostas não estão surtindo os efeitos desejados. A escassez destes trabalhos certamente fundamenta-se em dois principais problemas: a) a criação relativamente recente da instituição; b) e a dificuldade em face da ausência de dados compilados e registros sobre a atuação da instituição.

De se mencionar que a escassez de trabalhos não significa ausência deles. Na academia, especialmente nos últimos três anos, despontaram estudos de relevo sobre a atuação da Defensoria ou a ela relacionados ${ }^{13}$ - de alguma forma - com a temática da educação infantil. Este autor, inclusive, teve oportunidade de participar como entrevistado de alguns deles. Tais trabalhos surgiram com maior constância notadamente depois que a instituição tornou-se mais visível, ao participar do Grupo de Trabalho Interinstitucional de Educação Infantil (GTIEI), no caso emblemático das ações cíveis públicas, que culminaram na condenação (no final de 2013) da municipalidade de São Paulo, na criação

\footnotetext{
${ }^{12}$ Citamos alguns autores com estudos expressivos no tema: Carolina Martins Marinho; Adriana Aparecida Dragone Silveira; Oscar Vilhena Vieira; Eloísa Machado de Almeida; Mariângela Graciano; Fernanda Fernandes; Ester Rizzi; Salomão Ximenes; Alessandra Gotti; Nina Ranieri; Cury; Flavia Rosemberg Autores com menção completa nas referências bibliográficas (e que serão citados, ainda, ao longo deste trabalho).

${ }^{13}$ Dentre os trabalhos de relevância, que serviram de apoio para esta tese, podemos citar: Luiza Andrade Corrêa; Fayola Sant' Anna Cajuella; João Paulo Faustinoni e Silva - autores com menção completa nas referências bibliográficas (e que serão citados, ainda, ao longo deste trabalho).
} 
de 150 mil vagas para os destinatários da educação infantil. As entrevistas foram concedidas decorreu de nossa posição institucional, pois naquela época encontrava-se à frente da Assessoria Cível, Órgão da Administração da instituição, representando-a em muitos eventos e discussões que envolviam a temática da educação infantil.

A relevância da tese se acentua na medida em que faz um entrelaçamento da atuação da Defensoria não apenas em ações individuais, mas também em ações coletivas e no cenário das ações dialógicas (judicial e extrajudicial) em construção conjunta com demais poderes, em cotejo com a própria preparação, a implementação e a fiscalização de políticas públicas educacionais.

Desta maneira, permitirá revelar as possibilidades e limitações da atuação institucional frente ao sistema educacional, na condição de influenciar e alterar as falhas da política. Conforme já apontado por João Paulo Faustinoni e Silva ${ }^{14}$ com relação ao Ministério Público, que aqui se aplica igualmente para a Defensoria, importante explicitar que: “embora não caiba ao Ministério Público a elaboração ou execução das políticas públicas educacionais, o novo perfil constitucional da instituição e suas novas atribuições na defesa dos interesses sociais têm impulsionado demandas da própria sociedade para que atue nas diversas etapas do ciclo ${ }^{15}$ das políticas públicas".

A metodologia adotada para o desenvolvimento dos capítulos da tese, objetivando o enfrentamento da questão central delineada, buscou, em primeiro passo, contextualizar a educação infantil desde o cenário normativo até o judicial. Especialmente

\footnotetext{
${ }^{14}$ Faustinoni e Silva, João Paulo. Ministério Público e a defesa do direito à educação: subsídios teóricos e práticos para o necessário aperfeiçoamento institucional. Dissertação de mestrado. São Paulo: USP/Faculdade de Direito, 2018. p. 14.

15 O processo de elaboração de políticas públicas também é conhecido como ciclo de políticas públicas (policy cycle). O ciclo de políticas públicas é um esquema de visualização e interpretação que organiza a vida de uma política pública em fases sequenciais e interdependentes. Existem várias versões. Leonardo Secchi observa que em regra geral é composta por 7 fases principais: 1) Identificação do problema; 2) Formação da agenda; 3) Formulação de alternativas; 4) Tomada de decisões; 5) Implementação; 6) Avaliação; 7) Extinção. Apesar da utilidade heurística, Secchi observa que o ciclo de políticas públicas dificilmente reflete a real dinâmica de uma política pública, já que as fases em geral de apresentam de forma misturada e as sequências se alternam. Ex: soluções muitas vezes nascem antes dos problemas, como no modelo da lata de lixo. De modo que não há um ponto de início e um ponto de finalização da política pública, além do que as fronteiras entre as fases não são nítidas. A utilidade do ciclo de formações está na capacidade de auxiliar na organização da idéias, fazendo com que a complexidade de uma política pública seja simplificada e auxilia políticos, administradores e pesquisadores a criar um referencial comparativo para casos heterogêneos. (Leonardo SECCHI. Políticas Públicas - Conceitos, Esquemas de Análise, Casos Práticos. São Paulo: Cengage Learning, 2012. Capítulo 3 "Ciclo de Políticas Públicas").
} 
procurando evidenciar este movimento pendular que o tema da educação infantil sofreu ao longo dos anos, a partir da previsão na Constituição Federal de 1988.

$\mathrm{Na}$ verdade, com a constante insatisfação de seus destinatários, deu-se início à migração do direito - previsto e não cumprido- para dentro do Judiciário, como nova arena para efetivação da política pública educacional. Nesta caminhada, o Poder Judiciário passa a ser paulatinamente instado a participar, examinando o controle da política pública ${ }^{16}$ educacional. Em certo momento, tornou-se "o protagonista" da política. Prova disso, o julgamento paradigmático no Supremo Tribunal Federal ${ }^{17}$ e a mudança de perspectiva, passando o direito à educação ser visto como direito público subjetivo, exigível e não mera norma programática ${ }^{18}$. Algumas questões dantes intransponíveis, como a reserva do possível $^{19}$, a separação dos poderes e a impossibilidade de o Poder Judiciário imergir-se no exame da política passam a ser superadas.

\footnotetext{
${ }^{16}$ Freire Junior levanta dois níveis de controle judicial da política pública ao anotar que "para assegurar claramente a efetividade das políticas públicas em geral é necessário adotar uma política mais incisiva de controle judiciário. Nesse contexto, dois são os diferentes níveis de controle judiciário: o primeiro, as atividades de controle judiciário devem acontecer quando a administração não adota qualquer política para satisfazer as necessidades públicas da comunidade; o outro, quando a política é impropriamente adotada pela administração, implicando na falta de satisfação do interesse público ou, ao mesmo tempo, no mal uso do dinheiro público. Em ambos os casos, a missão do controle judiciário se mostra indispensável para assegurar a efetividade dos direitos fundamentais incluídos na constituição material". (FREIRE JÚNIOR, Américo Bedê. O controle judicial de políticas públicas. São Paulo: Editora Revista dos Tribunais, 2005).

${ }^{17}$ Recurso Extraordinário no ${ }^{\text {4 }}$ 410.715/SP, julgado em 22 de novembro de 2005, no qual o voto condutor do Ministro Celso de Mello determinou a obrigatoriedade de prestação de serviço de educação também para o ensino infantil.

${ }^{18}$ Corrêa confirma diversas posições doutrinárias do direito à educação protegido como direito fundamental: "Diferentemente do que acontece nos estudos sobre o direito à saúde, o estado da arte dos trabalhos sobre a judicialização da educação demonstra que mesmo os trabalhos empíricos têm como premissa a aplicabilidade obrigatória e imediata do direito fundamental à educação. Um ponto em comum entre a maior parte desses trabalhos é que adotam a premissa de que o Judiciário deve atuar para assegurar a promoção do direito subjetivo à educação, exaltando a faceta individual do direito subjetivo e desconsiderando sua dimensão coletiva, que se revela a partir de uma política pública estruturada.(...). Assim como no direito à saúde, a doutrina brasileira sobre direito à educação costuma compreendê-lo como um direito fundamental social, com uma faceta individual e outra coletiva. Entende, portanto, que seus titulares possuem direitos subjetivos, apesar de estarem sob o manto da reserva do possível por sua aplicação demandar recursos financeiros (Ranieri, Nina Beatriz Stocco, 2009). O direito à educação, no âmbito desta literatura, seria um pressuposto para o exercício da cidadania e um fim em si mesmo, já que estaria voltado para o desenvolvimento da pessoa e de sua dignidade (Arnesen, Erik, 2010). Em resumo, a doutrina compreende o direito à educação como um direito fundamental e, portanto, com eficácia plena e aplicabilidade imediata, sendo pressuposto para a qualificação para o trabalho, para a cidadania e dignidade, sendo oponível contra o Estado, a família e a sociedade (Arnesen, Erik, 2010; Ranieri, Nina Beatriz Stocco, 2009). Além disso, correntemente se afirma que o constituinte quis expressamente diferenciar o direito à educação e permitir sua exigibilidade por meio do Poder Judiciário quando afirmou em seu artigo 208 , $\S 1^{\circ}$, que o acesso ao ensino é direito público subjetivo, cujo não oferecimento pelo Poder Público, ou sua oferta irregular, implica responsabilidade da autoridade competente". (Arnesen, Erik, 2010; Duarte, 2004; Ranieri, Nina Beatriz Stocco, 2009. In: CORRÊA, Luiza Andrade. A judicialização da política de educação infantil no Tribunal de Justiça de São Paulo. São Paulo: USP / Faculdade de Direito, 2014. p. 39).

${ }^{19}$ A chamada reserva do possível foi desenvolvida na Alemanha, num contexto jurídico e social totalmente distinto da realidade histórico-concreta brasileira. Nestas diferentes ordens jurídicas concretas não variam
} 
Portanto, o primeiro capítulo traz o arcabouço normativo do tema educação e, também, o respectivo entendimento jurisprudencial interpretativo destas normas, tudo para contextualizar o tema no cenário jurídico. Este capítulo inaugural objetiva apresentar ao leitor a situação macro da educação infantil na conjuntura atual, levando em conta as modificações normativas e interpretativas desde a Constituição de 1988. Examina, ainda, algumas estratégias de atuação utilizada por instituições como o Ministério Público e ONGs voltadas para a atuação direta ao direito à educação, demonstrando que as atuações convencionais, como já sabido, não surtem mais efeito. Ao menos o de superar o déficit de vagas e a crise de qualidade na educação infantil.

Os três capítulos seguintes tratam dos aspectos institucionais organizacionais da Defensoria e de como estes refletem na atuação de seus membros e acabam, por consequência, em causar impacto final nas políticas educacionais. Cada um destes três capítulos examina a atuação da instituição na concretização do direito à educação infantil, sob ângulos diversos.

O primeiro deles leva em conta os aspectos institucionais da Defensoria em relação à atuação de seus membros em ações individuais. Trata-se da atuação mais expressiva da Defensoria, ao menos em números de ações ajuizadas, ${ }^{20}$ de quantidade de

apenas as formas de lutas, conquistas e realização e satisfação dos direitos, mas também os próprios paradigmas jurídicos aos quais se sujeitam. Assim, enquanto a Alemanha se insere entre os chamados países centrais, onde já existe um padrão ótimo de bem-estar social, o Brasil ainda é considerado um país periférico, onde milhares de pessoas não têm o que comer e são desprovidas de condições mínimas de existência digna, seja na área da saúde, educação, trabalho e moradia, seja na área de assistência sociais, de tal modo que a efetividade dos direitos sociais ainda depende da luta pelo direito entendida como processo de transformações econômicas e sociais, na medida em que estas forem necessárias para a concretização desses direitos. Para além disso e certamente como reflexo desse conjunto de necessidades básicas dos brasileiros, a Constituição de 1988 é essencialmente dirigente, eis que composta de uma enorme quantidade de normas que impõe ao Estado Brasileiro a realização de políticas públicas socialmente ativas voltadas ao atendimento dessas mesmas necessidades, fixado as diretivas, metas e os mandamentos que devem ser cumpridos pelo Estado Social na efetivação dos direitos sociais. Eis aí porque "as teorias desenvolvidas na Alemanha sobre a interpretação dos direitos sociais não podem ser facilmente transferidas pata a realidade brasileira, sem as devidas adaptações" (CUNHA JÚNIOR, Dirley da. A efetividade dos direitos fundamentais sociais e a reserva do possível. Leituras Complementares em Direito Constitucional. Direitos Humanos e Direitos Fundamentais. $3^{a}$ edição. São Paulo: JusPODIVM, 2008, p. 388).

${ }^{20}$ Conforme dados estatísticos levantados no setor de triagem da Defensoria, o número de casos de pedidos de vagas em creche encaminhados para as unidades foram: a) $11.075 \mathrm{em} \mathrm{2014;} \mathrm{b)} 18.503 \mathrm{em} \mathrm{2015;} \mathrm{c)} 18.786$ em 2016; d) 19.383 em 2017. Vale registrar que estes dados incluem apenas os casos de atendimentos que foram identificados como pedidos de vagas em creches e foram encaminhados para as respectivas unidades de destino da ação. Por exemplo, em 2016 entraram em contato no fone 0800 para agendamento de atendimento 32.474 pessoas informando que pretendiam tratar de pedidos de acesso à educação infantil, mas apenas 18.786 foram efetivamente atendidas. Não foram registradas exatamente as razões pelo absenteísmo 
demanda e de número de pessoas que procuram a instituição para a solução concreta de seu caso. Adianta-se, contudo, a percepção de que as ações individuais não são suficientes para o enfrentamento da questão do déficit de vagas na educação infantil ${ }^{21}$ e da qualidade de ensino desta etapa da educação. O fenômeno da judicialização ${ }^{22-23}$ da educação e a crítica ao modo atual de organização e atuação da Defensoria Pública em matéria de políticas públicas educacionais são também objeto de análise nesse contexto. Neste capítulo a organização institucional será checada levando em consideração alguns tópicos, como: o modo de ingresso na carreira e a quantidade de cargos de defensores que atuam com a temática da educação infantil, as unidades do estado que atuam com a temática, a existência (ou não) de procedimentos padronizados para nortear a atuação dos seus membros, a eventual falta de litigância estratégica institucional, a rotatividade de

dos casos. Mas, como regra são pessoas que: a) deixaram de comparecer para atendimento ou; b) não tinham o enquadramento de renda para serem atendidas pelos critérios de hipossuficiência da Defensoria e foram, assim, denegadas ou; c) de alguma forma desistiram, seja porque os filhos mudaram de faixa etária e não precisavam mais da creche, seja porque foram convocados para atendimento nos equipamentos e a demanda não se mostrava mais necessária.

21 “Desde o início das ações do movimento 'Creche para Todos' até hoje, a situação concreta da educação infantil não avançou muito, sendo possível identificar retrocessos na qualidade da oferta. Mesmo havendo alguma ampliação da disponibilidade de vagas, a própria Secretaria Municipal de Educação registrava, em setembro de 2009, uma demanda oficial não atendida de 95.449 crianças de até 3 anos. No caso da pré-escola também há grande exclusão, mesmo que em menor escala, como comprova a demanda oficial reconhecida pelo próprio Município - 36.124 crianças excluídas (Fonte: Portal da SME, Demanda Escolar). Ao mesmo tempo, há também nessa faixa etária de 0 a 6 anos incompletos um importante contingente populacional à espera de atendimento sequer cadastrado oficialmente, seja por não dispor da documentação e dos prérequisitos exigidos pela municipalidade, seja porque, sabendo que não será atendida, simplesmente não vê utilidade em procurar uma unidade de ensino oficial". Gotti. Op. Cit.

22 Alessandra Gotti realizou excelente pesquisa sobre a judicialização da educação básica no Brasil constatando que o Poder Judiciário tem sido profundamente demandado por vários temas da educação básica. Desde as tradicionais, como o acesso à educação em todas as sua etapas, mas também pelos mais recentes pleitos como o assunto do ensino domiciliar (homeschooling) e o da liberdade religiosa. No entanto, seu levantamento deixa assente de dúvida que o padrão de litigância na educação básica revelou um Poder Judiciário "intensamente mobilizado pela tutela de interesses particulares, com um perfil de litigância majoritariamente individual. As demandas com espectro coletivo ou difuso ainda se voltam ao acesso à educação e deparam com obstáculos processuais no caminho”. Seu artigo consigna que o acesso à educação infantil, em especial à creche, está no topo do ranking da judicialização. GOTTI, Alessandra. Um retrato da judicialização da educação Básica no Brasil. In: "Reflexões sobre Justiça e Educação". Organização Todos pela Educação. São Paulo: Editora Moderna, 2017, p. 45.Sobre homeschooling vale a leitura: RANIERI, Nina Beatriz Stocco. O novo cenário jurisprudencial do direito à educação no Brasil: o ensino domiciliar e outros casos no Supremo Tribunal Federal. DOSSIÊ: Homeschooling e o Direito à Educação. Caderno proposições. V. 28, N. 2 (83)| Maio/Ago. 2017.

23 Para Torres "o grande problema da judicialização dos direitos sociais consiste no seu caráter antidemocrático, eis que tais direitos se afirmam na via das eleições e das escolhas trágicas dos partidos políticos em torno de políticas públicas. As Cortes Constitucionais não podem agir contra as maiorias nas questões políticas, mas apenas nas decisões que afetam a jusfundamentalidade dos direitos; os direitos sociais, dependentes de argumentos de policy, não são trunfos contra a maioria, como os fundamentais. Além disso, as decisões casuísticas agravam as desigualdades entre as pessoas. No Brasil assiste-se à predação da renda pública pela classe média e pelos ricos, especialmente nos casos de remédios estrangeiros, com o risco de se criar um impasse institucional entre o Judiciário e os poderes políticos, se prevalecer a retórica dos direitos individuais para os sociais." TORRES, Ricardo Lobo. O Direito ao Mínimo Existencial, Rio de Janeiro/São Paulo/Recife: Renovar, 2009, p. 131-134. 
defensores nos cargos, a independência funcional do defensor, a enxurrada de ações individuais e o efeito "fura fila", a possibilidade de suspensão/interrupção de ajuizamento de ações individuais (obrigatoriedade de agir) em cotejo com a promoção do acesso à justiça, o funcionamento da comunicação interna e o compartilhamento de informações, a fragilidade de compilação de dados estatísticos de atuação institucional ${ }^{24}$ e a repetição de padrão de comportamento de ação.

O capítulo seguinte deste bloco analisa os aspectos organizacionais da Defensoria em relação à atuação de seus membros nas ações coletivas, em estreita relação com a própria elaboração, a execução e a fiscalização de políticas públicas educacionais, diferentemente do que ocorre na tutela de direitos individuais. A legitimidade dos Defensores Públicos em poder manejar ações civis públicas consiste em importante ferramenta de atuação. Todavia, a impressão inaugural nos leva a crer que o desenho organizacional institucional não estaria amadurecido para o emprego adequado e necessário deste mecanismo processual. Este capítulo contempla o exame de aspectos como a indefinição de um órgão específico para ser responsável por tais ações, a ausência de coordenação e posições efetivamente institucionais sobre temas sensíveis do direito à educação, de planejamento estratégico para enfrentamento coletivo e concatenado dos problemas na educação infantil, a carência de setor de apoio no auxílio da instrução das ações civis públicas e o eventual ajuizamento desorganizado. Para tanto, será feita uma exposição do funcionamento organizacional da instituição levando em conta: as atribuições do Defensor individual, que permite ele próprio ajuizar ação coletiva; a deliberação específica que trata de tutela coletiva; em cotejo com as atribuições e legitimidade de atuação por meio do núcleo especializado de infância e juventude da instituição. Novamente muitos aspectos esbarram em assuntos como a autonomia funcional versus subjetivismo de atuação, assim como feito no exame da atuação dos defensores em ações individuais.

\footnotetext{
${ }^{24}$ Fayola fez um relevante trabalho sobre a atuação da Defensoria. Em diversas passagens ressalta para a dificuldade da instituição em face da escassez de compilação de dados: "Em virtude da ausência de banco de dados e de classificação temática de documentos da DPE/SP e relatórios predominantemente quantitativos concentrados na Corregedoria-Geral, optou-se por realizar entrevistas para o preenchimento de lacunas da investigação". E em outra passagem: "durante a pesquisa, constatou-se a ausência de banco de dados ao encontro dessas manifestações favoráveis ao estímulo do exercício da atuação em tutela coletiva, ainda que nos dias atuais, a partir do uso das novas tecnologias, o peticionamento eletrônico e a digitalização de processos sejam instrumentos de uso diário entre os Defensores Públicos na área cível”. Cajuella, Fayola Sant' Anna. O acesso à justiça e o direito à educação infantil: um estudo sobre a atuação da Defensoria Pública do Estado de São Paulo / Fayola Sant'Anna Cajuella. 2016, p. 90, dissertação de mestrado, FGV.
} 
O capítulo que fecha este bloco examina os aspectos organizacionais institucionais frente à possibilidade de atuação de seus membros nas ações dialógicas, entendidas aqui neste estudo por aquelas combinações sejam judiciais ou não, mas que envolvem diversos atores que podem conjuntamente construir uma solução consensuada, de forma estruturante. Neste capítulo específico abordamos a atuação da instituição no "leading case" do GTIEI - Grupo de atuação interinstitucional de educação infantil. O GTIEI, do qual a Defensoria faz parte, perseguiu uma negociação junto à municipalidade de São Paulo, com intermediação do Poder Judiciário, que culminou na decisão ${ }^{25}$ do dever de disponibilização de 150 mil vagas na educação infantil. Portanto, este capítulo tem por missão examinar se a Defensoria encontra-se apta e preparada organizacionalmente para participar destas construções coletivas.

Ao longo destes três capítulos que tratam da organização institucional nas três diferentes frentes de atuação, pretende-se fazer uma análise crítica dos obstáculos enfrentados em cada uma destas formas de atuar. Notadamente tentando explicitar os procedimentos em exercício que não funcionam ou não atingem os objetivos perseguidos.

\footnotetext{
${ }^{25}$ A parte final do decisum do v. acórdão da apelação n ${ }^{\circ}$ 0150735-64.2008.8.26.0002 da lavra do Des. Walter de Almeida Guilherme, do TJSP, assim consignou: "X - Destarte, a decisão que julgou improcedente a ação civil pública é reformada, de forma a: 1. Obrigar o Município de São Paulo a criar, entre os anos de 2014 e 2016, no mínimo, 150 (cento e cinquenta) mil novas vagas em creches e em pré-escolas para crianças de zero a cinco anos de idade, disponibilizando 50\% (cinquenta por cento) nos primeiros 18 (dezoito) meses, das quais 105 (cento e cinco mil) em tempo integral em creche para crianças de zero a 3 (três) anos idade, de forma a eliminar a lista de espera, garantida a qualidade da educação ofertada, observando-se para tanto, quer quanto as unidades de ensino já existentes na rede escolar, quer referentemente àquelas que vierem a ser criada, as normas básicas editadas pelo Conselho Nacional de Educação e, suplementarmente, aquelas expedidas pelo Conselho Municipal de Educação. 2. Obrigar o Município de São Paulo a incluir na proposta orçamentária a ampliação da rede de ensino atinente à educação infantil de acordo com a ampliação determinada. 3. Obrigar o Município de São Paulo a apresentar a este Juízo, no prazo máximo de 60 (sessenta) dias, plano de ampliação de vagas e de construção de unidades de educação infantil para atendimento do estipulado no item "1". 4. Obrigar o Município de São Paulo a apresentar, semestralmente, relatórios completos sobre as medidas tomadas para efeito do cumprimento da obrigação fixada no item "1". A esses relatórios terão acesso, no exercício de monitoramento, a Coordenadoria da Infância e da Juventude, a quem caberá, como posto no Acórdão que apreciou o Agravo Regimental já mencionado, fornecer ao Juízo, bimestralmente, informações sobre o cumprimento do julgado e articular com a sociedade civil e com outros órgãos do Tribunal, com a Defensoria Pública e com o Ministério Público, se necessário, a forma de acompanhamento da execução da decisão, seja no tocante à criação de novas vagas, seja no referente ao oferecimento de educação com qualidade, nos termos do que está sendo determinado. Fica claro que esse monitoramento não retira do Juiz do processo o poder de determinar, de ofício ou a requerimento das partes, outras medidas que se fizerem necessárias, para que a decisão tenha efetividade. Uma vez ordenada prestação de informações pela Municipalidade de São Paulo, bem como o acesso a elas que terão os órgãos referidos, não há razão para fixar penalidade pelo descumprimento das obrigações impostas e, com sugerido pelas apelantes em memorial, o bloqueio de verbas, para remanejamento, das rubricas orçamentárias destinadas à publicidade institucional na Lei Orçamentária em vigor, sendo certo, ademais, que, a qualquer momento o Juiz do processo, poderá fixar astreintes para compelir os responsáveis a cumprir as determinações. XI - Em conclusão, dou parcial provimento ao recurso".
} 
Certo que alguns pontos que circundam a questão central da tese deverão ser enfrentados, tais como: a necessidade de especialização e talvez de regionalização de Defensorias públicas de educação; a institucionalização de espaços e procedimentos de construção democrática de planejamento estratégico, verificando se os que existem atualmente são eficientes e/ou suficientes; a avaliação acerca da possibilidade de priorização de demandas coletivamente acordadas em sínteses de consenso, em contraposição à atuação individualizada ou ainda que de grupos esparsos e desarticulados; bem como a construção de repertórios de casos e exame da eficiência das teses institucionais, de modo a provocar clarividência na atuação institucional ${ }^{26}$.

Alguns recortes foram selecionados para delimitar o objeto da pesquisa, que merecem esclarecimentos. A Defensoria Pública - como se verá ao longo da tese - possui legitimidade e tem dever de promoção dos direitos fundamentais em sentido amplo. No caso, o objeto restou delimitado no tema da educação infantil (creches e pré-escolas). No entanto, não se pode perder de vista que a instituição atua na garantia do direito educacional em sentido amplo. A educação infantil será investigada já que causa maior esforço e demanda de tempo na atuação do Defensor.

No que se refere ao lapso temporal, optou-se por partir da análise normativa do direito educacional a partir da Constituição Federal de $1988^{27}$. Entretanto, o exame do

\footnotetext{
${ }^{26}$ Maria Paula Dallari Bucci trata da institucionalização relacionada à política pública. Para Bucci, o adjetivo institucional refere-se ao conjunto de estruturas jurídicas, políticas e sociais que o tornam um objeto definido, distinto do ambiente que o cerca, a partir de certa ordenação e unidade funcional sedimentada, que produz a reiteração de determinados comportamentos. A autora caracteriza a institucionalização pelos seguintes traços: a) objetivação, descolamento em relação ao governo ou gestor que institui o programa; b) um padrão de organização; c) a juridificação desse padrão organizativo, baseada na formalização e nos elementos jurídicos que o definem, que distribui posições e situações jurídicas subjetivas dos diversos atores, cujo exercício movimenta o programa de ação e lhe confere vida concreta; d) uma idéia-diretriz, isto é, um principio referencial, que orienta todos os atores e atos envolvidos naquele arranjo, associado ao plano de ação. Depois, conceitua arranjo institucional como a locução que conota o agregado de disposições, medidas e iniciativas em torno da ação governamental, em sua expressão exterior, com um sentido sistemático. $\mathrm{O}$ arranjo institucional de uma política compreende seu marco geral de ação, incluindo uma norma instituidora, da qual conste o quadro geral de organização da atuação do Poder Público, com a discriminação das autoridades competentes, as decisões previstas para a concretização da política, além do balizamento geral das condutas dos agentes privados envolvidos, tanto os protagonistas da política quanto seus destinatários ou pessoas e ente por ela afetados. (Maria Paula Dallari BUCCI. Fundamentos para uma teoria jurídica das políticas públicas. $1^{\mathrm{a}}$ edição, $2^{\mathrm{a}}$ tiragem. São Paulo: Editora Saraiva, 2013, cap. 3. pp. 205-284).

${ }^{27}$ A Constituição de 1988, não sem razão, tem sido qualificada como delineadora de um Estado Democrático e Social de Direito, pois "expande a previsão de direitos sociais, compromete-se com múltiplos deveres consubstanciados na realização de políticas públicas e juridicamente vincula os três Poderes Públicos à realização de metas transformadoras da realidade social" (Gotti, Alessandra Direitos sociais: fundamentos, regime jurídico, implementação e aferição de resultados / Alessandra Gotti. - São Paulo: Saraiva, 2012, p. 24).
} 
desenho organizacional da atuação da Defensoria estará circunscrito a partir do ano de 2006, ano de sua criação ${ }^{28}$, até o ano de 2019, lapso final selecionado para traçar as conclusões deste trabalho.

No que tange ao recorte espacial, levando em conta que a Defensoria possui unidades espalhadas em todo o Estado, a abrangência levará em consideração os limites do Estado de São Paulo. Contudo, embora traçando um panorama estatal, pois a estrutura organizacional deveria valer, em tese, para todo o Estado $^{29}$, a tese tem concentração maior com relação à atuação da Defensoria no Município de São Paulo, levando em conta as suas especificidades. Isto porque: a) existe maior número de Defensores lotados nesta comarca, de modo que a atuação de per si é maior; b) é no Município de São Paulo que se encontra o maior déficit educacional e onde o problema apresenta proporções visivelmente maiores e mais preocupante (e que se repetem em menor proporção nos demais municípios) e c) foi no Município de São Paulo que se deu a atuação inovadora do Grupo de atuação interinstitucional de educação infantil, que será analisada no decorrer do estudo e que pode ser replicada para outros municípios.

\footnotetext{
${ }^{28}$ Em São Paulo, a Defensoria Pública do Estado só foi criada em 2006, por meio da Lei Complementar Estadual $n^{\circ}$ 988, quase 18 anos após ter sido prevista pela atual Constituição, em 1988. A promulgação dessa lei ocorreu em função de crescente pressão feita por diversos setores da sociedade e ampla mobilização social - o que culminou na criação do "Movimento pela Criação da Defensoria" em meados de 2002, envolvendo cerca de 440 entidades de diversos setores da sociedade civil (fonte sitio da Defensoria Pública do Estado de São Paulo). Conforme Schubsky, "a iniciativa visava sensibilizar os parlamentares estaduais, organizando petições e manifestações públicas e buscando apoio junto à comunidade jurídica e do sistema político, acerca da importância de se cumprir a Constituição Federal e instituir a Defensoria Pública do Estado de São Paulo" (Schubsky, Cássio (2008). Advocacia pública: apontamentos sobre a história da Procuradoria Geral do Estado de São Paulo $1^{\mathrm{a}}$ ed. São Paulo: Imprensa Oficial do Estado de São Paulo. p. 104-115). A Assembleia Legislativa paulista aprovou em 14 de dezembro de 2005 o Projeto de Lei Complementar $\mathrm{n}^{\circ} 18$, depois sancionado pelo governador Geraldo Alckmin, criando a instituição no Estado, um marco da democratização do acesso à Justiça e da defesa pública dos cidadãos e cidadãs carentes e vulneráveis, que passou a ser feita por uma instituição autônoma e independente. Até então, o serviço de assistência jurídica gratuita à população carente era feito pela Procuradoria de Assistência Judiciária (PAJ), criada por lei estadual em 1947. A PAJ era um sub-órgão da Procuradoria Geral do Estado, instituição prevista para prestar serviços jurídicos ao Governo do Estado. Apesar de a PAJ ter conquistado enorme reconhecimento em função da qualidade de sua atuação perante o Judiciário, a criação da Defensoria Pública foi o marco pelo qual a população carente do Estado passou a ser atendida por uma instituição autônoma e independente. Procuradores e Procuradoras do Estado que atuassem na PAJ puderam optar pela Defensoria Pública. 87 pessoas, ao total, optaram por esse caminho. Essa opção foi considerada constitucional pelo Supremo Tribunal Federal (STF), que entendeu que houve uma cisão da Procuradoria Geral do Estado, antes composta por três sub-órgãos: Consultoria Jurídica, Contencioso Jurídico e Assistência Jurídica Gratuita, este último a PAJ. Cristina Guelfi Gonçalves foi nomeada em 15 de maio de 2006 a primeira Defensora Pública-Geral, ocupando o cargo por dois mandatos.

${ }^{29} \mathrm{Na}$ prática será demonstrado que a organização institucional não segue o mesmo padrão levando em conta as peculiaridades locais. Por exemplo: número de defensores, tema de atuação, absorção pela própria instituição das demandas ou repasse ao convênio, atendimento fracionado ou integral na mesma unidade etc.
} 
Ambiciona, assim, finalizar a tese respondendo ao questionamento central desvendando se a Defensoria Pública do Estado de São Paulo, no campo da concretização do direito à educação infantil, está institucionalmente organizada para desincumbir-se dos deveres constitucionais impostos a ela. É nesta fase final que se pretende, também, apresentar as propostas para o aperfeiçoamento da atuação institucional face sua missão constitucional de efetivação da educação infantil.

O diagnóstico da organização institucional refletida na atuação da Defensoria na área da educação infantil consiste em verdadeira contribuição, não apenas para o mundo acadêmico, que poderá conhecer em detalhes a atuação da instituição. Mas também, para o sistema de Justiça, fornecendo subsídios para a compreensão da atuação da Defensoria, do Judiciário e do próprio Executivo, na formulação da política pública ${ }^{30}$. Mais ainda, o estudo da organização institucional poderá diagnosticar as falhas de atuação e apresentar as propostas para encontrar meios eficientes de concretização do direito à educação infantil.

\footnotetext{
${ }^{30}$ Capella apresenta dois modelos teóricos para compreensão da formulação de políticas públicas, dando ênfase no processo de formação da agenda de políticas governamentais. O primeiro chamado de Múltiplos fluxos (Multiple Streams Model), desenvolvido por John Kingdom considera as políticas públicas como um conjunto formado por 4 processos: a) estabelecimento de uma agenda de políticas públicas; b) consideração das alternativas para formulação das políticas públicas; c) a escolha dominante entre o conjunto de alternativas; d) a implementação da decisão. Neste modelo a agenda governamental é definida como o conjunto de assuntos sobre os quais o governo e pessoas ligadas a ele concentram sua atenção em determinado momento. Assim, uma questão passa a fazer parte da agenda governamental quando desperta a atenção e o interesse dos formuladores de políticas. No modelo de Kingdom de multiple streams as questões são bem-sucedidas e são alçadas à agenda governamental quando existe a confluência entre os fluxos (coupling) pelos empreendedores. O segundo modelo chamado de equilíbrio pontuado (Punctuated Equilibrium Model), foi desenvolvido por Frank Baumgartner e Brian Jones e inicialmente formulado para analisar o processo político norte-americano. Se aprofunda na reflexão sobre as instituições, trazendo proposições importantes sobre a relação entre a formulação da agenda e a dinâmica institucional. Os autores procuram criar um mecanismo que permite a análise tanto de períodos de estabilidade, como aqueles em que ocorrem mudanças rápidas no processo de formulação de políticas públicas. Longos períodos de estabilidade, com mudanças de forma lenta e gradual são interrompidos por momentos de rápidas mudanças (=punctuations). Essa idéia é aplicada às agendas que mudam de forma rápida devido ao feedback positivo, isto é, algumas questões se tornam importantes, atraindo outras que se difundem como um efeito cascata (=bandawagon). Ana Cláudia N. CAPELLA. Perspectivas teóricas sobre o processo de formulação de políticas públicas. In Políticas Públicas no Brasil (Gilberto Hochman, Marta Arretche e Eduardo Marques, orgs.). Rio de Janeiro: Editora Fiocruz, 2007, pp87-124.
} 


\section{CONSIDERAÇÕES FINAIS}

A Constituição Federal vigente, em seu capítulo IV (com redação dada pela Emenda Constitucional $n^{\circ}$ 80, de 2014), ao tratar das funções essenciais à Justiça, institui a Defensoria Pública - ao lado do Ministério Público e da Advocacia (pública e privada) como instituições responsáveis para o desempenho de tais funções.

Em que pese a previsão constitucional desde a promulgação de seu texto em 1988, fato é que a Defensoria Pública do Estado de São Paulo, nos moldes previstos para exercer a orientação jurídica, a promoção dos direitos humanos e a defesa, em todos os graus, judicial e extrajudicial, dos direitos individuais e coletivos, de forma integral e gratuita, aos necessitados, foi criada apenas no ano de 2006. Durante este período, as funções da Defensoria foram exercidas de forma "paliativa" pela Procuradoria de Assistência Judiciária (P.A.J.).

A criação da instituição veio cercada de esperança, com força e apoio da sociedade civil e com diversos instrumentos processuais e extraprocessuais previstos na Lei Complementar 988/2006, que organiza a Defensoria Pública do Estado, notadamente a legitimidade para ajuizamento de ação civil pública para tutela de interesse difuso, coletivo ou individual homogêneo dos necessitados. Em pouco tempo a instituição ganhou visibilidade e obteve reconhecimento pela prestação de seus serviços. Em muitas oportunidades acabou por assumir espaços dantes ocupados e exercidos pelo Ministério Público, o que lhe trouxe ainda mais notoriedade.

No entanto, logo nos primeiros anos de criação, a Defensoria passou a experimentar as dificuldades de uma instituição nova, cujo desenho organizacional ainda vivenciava experimentos de erros e acertos e cujo modelo anterior herdado da antiga P.A.J. ainda permanecia arraigado - em sua essência - na maioria dos pensamentos e procedimentos até então adotados. A sucessão de uma instituição existente por outra "nova", mas que passaria a exercer funções semelhantes dificultou a adoção de uma identidade própria. Em muitas oportunidades via-se uma continuidade automatizada de métodos implementados outrora, sendo repetidos de forma instintiva. Na verdade, ao novo desenho normativo da Defensoria haveria de corresponder um novo arranjo institucional. 
Instituições são construções sociais e, assim como dependem da ação das pessoas que as integram, necessitam estabelecer estruturas e procedimentos que instiguem e estimulem seus membros a perseguirem de modo eficaz os fins para os quais foram criadas, sob pena de se deslegitimarem perante a sociedade e, no extremo, submergirem sua própria razão de existir.

Como membro integrante da instituição desde o ano de 2007 (condição esta revelada desde a abertura do trabalho, justamente para - de forma ética - situar o local de onde partia a observação e ponto de percepção do objeto de pesquisa) foi possível notar, logo no início de nossa atuação, que um dos maiores desafios da instituição consiste na garantia do acesso às vagas em creches e pré-escolas para crianças de zero a cinco anos. A segunda maior demanda em termos quantitativos da área cível. De modo que entendeu que seria possível desenvolver uma pesquisa, distanciada do caráter subjetivo, porém, sem deixar de realizar uma análise crítica do arranjo institucional da Defensoria Pública na efetivação do direito à educação.

Toda pesquisa realizada a partir da percepção de quem, de certa forma, integra o objeto maior de investigação, traz pontos positivos e negativos. De um lado, a experiência prática vivenciada na rotina da instituição por mais de doze anos afiançam certa segurança e propriedade daquilo que é narrado. Por óbvio que a condição de Defensor Público do Estado proporcionou importante intercâmbio com defensores, juízes e promotores, além de operadores do direito envolvidos na causa da educação infantil, fomentando a troca de informações e experiências. Vale destacar, ainda, o rico contato com secretarias e diretorias de ensino, bem como professores e gestores da educação, além da coletividade em geral, formada especialmente por pais e mães de alunos. De outro, houve uma constante preocupação e atenção para evitar que o trabalho acadêmico fosse contaminado por impressões pessoais. Portanto, buscamos demonstrar que a observação rotineira encontrava respaldo na pesquisa. Procuramos, a todo tempo, tentar manter o equilíbrio objetivando que a prática, viesse devidamente embasada em subsídios teóricos, além de dados estatísticos, para resultar em um trabalho socialmente útil.

Aliás, o crescente desejo de tratar do tema foi impulsionado pelas agruras experimentadas na rotina diária institucional, nos desafiando a examinar o assunto em 
profundidade, para sugerir prováveis medidas para o aperfeiçoamento da atuação institucional e organização da Defensoria Pública. Todos os questionamentos decorrentes destas agonias, então, foram consolidados em uma pergunta central que esta tese buscou responder: a Defensoria Pública do Estado de São Paulo, na seara da concretização do direito à educação infantil, está institucionalmente organizada para desincumbir-se com validade e eficiência dos deveres que lhe foram constitucionalmente impostos?

Alertamos, ainda, que a pesquisa não visava ao exame individualizado da atuação dos membros da Defensoria. Quer dizer, não se intentava descrever boas práticas ou, ao contrário, apontar condutas eventualmente desviada deste ou daquele Defensor. O escopo consistiu na verificação da Defensoria enquanto instituição, isto é, dos aspectos institucionais e de como estes refletem na atuação de seus membros e acabam por ter impacto final nas políticas educacionais. Destarte, um exame de como se desenha a organização institucional da Defensoria, para a obtenção de sua missão educacional, não se debruçando de forma geral e alargada sobre o aspecto formal do conjunto de normas que delineiam a instituição.

Naquele momento introdutório, apenas pelas colocações iniciais, sem a inteireza da pesquisa efetivamente realizada, como foi ao longo deste trabalho, nos parecia que a formulação da questão central, assim como a hipótese inicial de resposta seria - ao menos - parcialmente negativa. E, nas considerações finais deste trabalho, podemos asseverar que de fato a Defensoria carece de diversos ajustes e da adoção de algumas providências se pretende estar institucionalmente preparada para a materialização dos dispositivos normativos concernentes ao direito à educação infantil. Chegamos à conclusão que os Defensores exercem um trabalho de excelência, são reconhecidos e valorosos no desempenho de suas atribuições. Inclusive existe um reconhecimento da sociedade e da comunidade jurídica em geral pelos serviços de excelência. Contudo, a Defensoria enquanto ente maior não está institucionalmente organizada para desincumbir-se com validade e eficiência dos deveres que lhe foram constitucionalmente impostos.

Para o exame da questão central desta tese, após apresentar um panorama geral do direito educacional no capítulo inaugural, analisamos a organização institucional da Defensoria sob 3 enfoques: a) em relação à atuação de seus membros nas ações individuais; b) em relação à atuação de seus membros por meio das ações coletivas; c) em 
relação à possibilidade de atuação nas chamadas ações estruturantes, que preferimos caracterizar como ações judiciais ou extrajudiciais dialógicas.

O primeiro deles levou em conta os aspectos institucionais da Defensoria em relação à atuação de seus membros em ações individuais, atuação mais contundente da instituição, ao menos em quantidade. A Defensoria nasceu, cresceu e avançou rapidamente, de maneira aguerrida, mas de certa forma desordenada, presa a estruturas e formas de atuação profundamente marcadas por sua origem na tutela eminentemente de cunho individual de direitos dos hipossuficientes, embora legitimada a atuar de forma coletiva e global. Assim, a Defensoria além de ancorada na pregação da filosofia de solução individual da demanda, sofre institucionalmente com sua organização, para ultrapassar este modelo obsoleto. Sem contar que o modelo de judicialização individual encontra-se saturado.

Em que pesem os diversos dispositivos garantindo o direito à educação, a Defensoria sofre com a diminuta quantidade de cargos de defensores que atuam com a temática da educação infantil. Analisamos os números da instituição e constatamos que dos (aproximadamente) 750 defensores espalhados pelas unidades do Estado de São Paulo, apenas 86 destes possuem atribuição para atuação na infância e juventude cível. Portanto, somente pouco mais de $10 \%$ da totalidade dos Defensores de todo o Estado de São Paulo possuem atribuição - e ainda cumulada com outras - para atuar na temática de infância e juventude cível, enfrentando questões da educação infantil. Desta forma, o reduzido número de membros dificulta, sobremaneira, combater as falhas e omissões da política pública educacional. A Defensoria está instalada em poucas comarcas, com poucos membros destinados ao enfrentamento dos gargalos educacionais.

Sem contar que deste seleto grupo, temos que muitos membros ingressam na carreira e de acordo com a posição no concurso e local de atuação passam a atuar com a temática da educação, sem qualquer inclinação para tanto, com pouca bagagem no assunto, já que se trata de um tema notadamente específico e delicado. Defendemos firmemente a capacidade de todos defensores em lidar com todos os assuntos. Não é disto que se trata. Mas, da possibilidade de se pensar mecanismos de seleção para uma atuação tão específica e delicada. Não chegamos a uma sugestão certeira para alterar este cenário, uma vez que o critério objetivo do concurso que verifica a posição e a vacância de vaga ainda parece o 
mais justo. Mas, cria muitas vezes um abismo entre a obrigatoriedade e a habilidade para tratar do assunto.

Outro ponto de evidente dificuldade causado pelo desenho organizacional está na questão da substituição dos titulares dos cargos que tenham atribuição na área da infância e juventude cível, vez que na ausência dos titulares, os substitutos podem nem sequer ter atribuição específica na temática e acabam assumindo os processos e atendimentos dos usuários nesta área, sem uma maior familiaridade. A rotatividade de defensores nos cargos também causa prejuízo para a continuidade de atuação. Agora, nestas situações, para além da inexistência de defensor com atuação exclusiva na infância e juventude relacionada com a questão da educação, exsurge uma discussão imprescindível: a ausência de Defensorias Regionais de educação, que poderiam ter atribuição especializada para o tema, contendo com membros que poderiam se substituir entre si nas ausências e vacâncias e poder contar com uma atuação em equipe, com atribuição exclusiva na área.

O desenho institucional vigente, cujo defensor tem atribuição de atuação individual nos limites estritos da comarca, e no caso da Defensoria, limitado até mesmo a um foro local, causa um descompasso para o enfrentamento da política educacional, porquanto esta última extrapola o limite territorial. Além disso, neste desenho organizacional da Defensoria, o Defensor acaba sendo levado a ter uma atuação solitária e individualizada, na medida em que responde sozinho pelos processos de uma localidade restrita, sobrecarregado com outros afazeres, na maioria das vezes sem tempo para contato com outros agentes da política. Submerge em intervenções de subsunção de fatos à norma e em procedimentos padronizados nos quais os processos viram meras estatísticas a serem vencidas rotineiramente.

A atuação pela via das ações individuais sofre, igualmente, com a organização institucional posta, na medida em que o atendimento é fracionado em diversas etapas, em diversos locais de atendimento, com defensores variados. Mesmo com os avanços adotados pela Defensoria, como o atendimento expresso concentrado na triagem para os casos de pedidos de vagas em creche, ou seja, de acesso à educação infantil, de se notar que o esforçou gerou melhoria tão somente procedimental. Mas, a atuação tornou-se ainda mais mecanizada, sem a devida qualidade na intervenção no problema central educacional. 
Ataca-se a consequência e não a causa. A mecanicidade de atuação e a continuidade do modelo de ação individual, sem obtenção de uma resposta eficiente, provocou uma crise interna na Defensoria. Passou-se a questionar se a atuação institucional estava chancelando um desvirtuamento da política pública educacional, porquanto não resolvia o problema e ainda causava uma inversão na ordem da fila de espera das crianças matriculadas, que estavam aguardando pela vaga na educação infantil. Tema polêmico que no Ministério Público chegou-se à conclusão pela possibilidade de suspensão das ações individuais. No entanto, embora não enfrentado este tema, a Defensoria segue ajuizamento maciçamente as ações individuais, sob argumento de que: a) trata-se de instituição que deve garantir aos necessitados o acesso à justiça, não podendo cerrar suas portas, diante da possibilidade jurídica da demanda e; b) como forma de pressionar o Pode Público municipal para que não se acomode diante do descumprimento da política educacional.

A ausência de uma diretriz institucional deixa de nortear a atuação do defensor, já que não há um posicionamento institucional da forma como lidar com a temática. Se internamente a questão padece desta ausência de planejamento estratégico, externamente, com a assunção da atuação em diversas comarcas do Estado pelos conveniados, em especial pela Ordem dos Advogados do Brasil, a pulverização de entendimentos e liberdade de atuação causa ainda maior desencontro de unicidade de agir. Esse cenário deixa de propiciar um enfrentamento concatenado, harmônico e combinado para fazer valer os dispositivos constitucionais relacionados ao direito à educação.

Mas não é só. O número reduzido de defensores, especialmente aqueles com atribuições na infância e juventude; a atuação repetitiva e mecanizada sem estratégia, em face da elevada carga de trabalho e somatória de outras atribuições no mesmo cargo; a rotatividade e os afastamentos dos atuantes nos cargos com atribuição na infância e juventude, sem a existência de um núcleo ou grupo de defensores atuantes na temática são situações agravadas, ainda mais, pela alocação de defensores em locais de atuação sem um mapeamento aprofundado, que poderia revelar as comarcas mais sensíveis e prejudicadas pela deficiência da efetivação da política pública educacional. De fato, a expansão da Defensoria carece de um planejamento de médio e longo prazo, com critérios bem delineados, para efetiva concretização dos direitos fundamentais. 
A atuação individualizada padece com a independência funcional de seus membros. Defendemos fortemente ao longo do trabalho a independência funcional, justamente por se tratar de princípio institucional e garantia do defensor para uma atuação que não sofra interferências internas e externas. Todavia, justamente no ponto de nosso estudo, qual seja, a organização institucional para consolidação dos ditames educacionais, entendemos que deveria existir uma "flexibilização" da independência funcional, tão somente no sentido de possibilitar e expedição de coordenadas estratégicas de atuação, articulada pelo órgão legitimado (Conselho Superior), em consonância com o Defensor Público-Geral e com oitiva/consulta aos membros da carreira. Tais coordenadas, respeitadas as normas legais e no limite da permissão das atribuições ao órgão legitimado e desde que no interesse final dos necessitados, que são os destinatários constitucionalmente assegurados dos serviços prestados pela Defensoria Pública, poderiam instituir os nortes de atuação estratégica que hoje falta à instituição. Há uma resistência e uma ojeriza em não se aceitar qualquer orientação ou diretriz sob alegação de imposição de atuação e ingerência sob a independência funcional. Porém, como instituir um planejamento estratégico de atuação permeada por todo uma instituição de alcance estadual sem coordenadas uniformes?

Uma atuação que alcança e afeta milhares de pessoas acerca de um tema específico, não pode ficar na discricionariedade exclusiva de cada membro da Defensoria, não se tratando, in casu, de independência funcional, mas ajuste de estratégia de atuação. Lembramos que a Defensoria dispõe de alguns institutos que poderiam - de certa maneira - implementar esta ideia das coordenadas estratégicas de atuação, tais como as recomendações, os parâmetros mínimos de qualidade, as rotinas administrativas. Porém, nenhuma delas foi expedida no que se refere à institucionalização da educação infantil.

Nos aspectos organizacionais da Defensoria em relação à atuação de seus membros nas ações coletivas, em estreita relação com a própria elaboração, execução e fiscalização das políticas públicas educacionais, igualmente do que ocorre na tutela de direitos individuais, a instituição sofre reveses por conta de seu desenho estrutural.

Em que pese a legitimidade da Defensoria em poder manejar ações civis públicas, que consiste em importante ferramenta de atuação, a indefinição de um órgão específico para ser responsável por tais ações, a ausência de coordenação e posições 
efetivamente institucionais sobre temas sensíveis do direito à educação, bem como a carência de setor de apoio no auxílio da instrução das ações civis públicas, refletem o panorama de imaturidade na atuação pela via coletiva, com ajuizamento desorganizado, em situações pontuais, revelando verdadeiro subjetivismo.

Neste aspecto, o principal entrave incide na ausência de implementação da Deliberação do Conselho Superior $n^{\circ} 139$ que trata das Defensorias das tutelas coletivas. Até hoje, passados mais de doze anos da criação da instituição, não houve a criação de tais defensorias. Isso produz uma insegurança, subjetivismo e acomodação e, acima de tudo, discricionariedade de atuação, na medida em que Defensores de forma individual ou os núcleos temáticos podem ajuizar ações coletivas, se assim desejarem, sem qualquer tipo de controle. Não se quer engessar a carreira, nem tampouco impedir a livre atuação dos defensores em verdadeiro monitoramento ideológico. O que se revelou foi a lacuna prejudicial causada pela inércia na criação das defensorias de tutela coletiva, que provocam todo este cenário de fragilidade institucional.

A implementação das defensorias das tutelas coletivas representa elemento essencial na construção da identidade e questão de eficiência dos serviços da Defensoria, relegada ao voluntarismo, ao improviso e à precariedade. A efetiva adoção das defensorias de tutela coletiva poderia alavancar a litigância estratégica. Não significaria a instalação de defensorias regionais de educação, porém seria um passo para uma especialização de atuação, na medida em que, em cada unidade existiria uma defensoria definida e identificada para tratar de questões coletivas, permitindo um planejamento encadeado e integral para enfrentamento da política educacional. Essa implementação identifica o legitima pela atuação, diminuindo o atual voluntarismo no manejo das ações coletivas.

Ainda no exame da atuação coletiva a instituição carece avançar na questão de compilação de dados e estatísticas. Embora a normativa destine aos núcleos temáticos a obrigação de organização dos dados, na prática essa coleta é falha. Além do mais, os núcleos carecem revisar seu desenho institucional. Atualmente o núcleo da infância e juventude possui natureza híbrida, composto por a) dois defensores coordenadores afastados que organizam e administram a atuação do núcleo, na maioria das vezes sobrecarregados pela acumulação da gestão com a atuação jurídica de temas importantes em diversas ações judiciais e; b) quinze defensores integrantes cujas atribuições ordinárias 
podem não guardar qualquer pertinência com a temática da infância e juventude e que atuam apenas de forma esporádica, por um período de tempo limitado como colaboradores, o que acaba não promovendo um envolvimento efetivo e perene na solução dos problemas educacionais. O núcleo da infância e da juventude tem sede na capital, com dificuldade de acesso para os defensores lotados na região metropolitana e comarcas do interior e também amarguram com a precariedade de sua estrutura material, humana e corpo técnico. Para melhor possibilitar o ajuizamento de ações coletivas, é preciso criar mecanismos como centros de apoio técnicos que possam efetivamente subsidiar o Defensor no procedimento preparatório da ação civil pública.

Na lei orgânica da Defensoria Pública existem instrumentos institucionais para construção de uma atuação estratégica. Contudo, verificamos que tais ferramentas não estão funcionando, ou ao menos não se têm alcançado os objetivos para aquilo que são previstas. Exemplo maior consiste no Ciclo de Conferências preparatórias para a Conferência Estadual e cujas diretrizes aprovadas nesta última comporão o Plano Anual de Atuação da Defensoria. A participação social esvaziada, além de uma considerável distância daquelas propostas que efetivamente são aprovadas nas Conferências Estaduais e aquilo que realmente tem significado importante para a instituição e que merece ser posto em prática, bem como a falta de indicação da forma, meios materiais e financeiros de efetivá-las, acabam constituindo letra morta.

Por fim, realizamos um exame das condições organizacionais institucionais frente à possibilidade de atuação de seus membros em ações dialógicas, entendidas aqui nesta tese por aquelas combinações sejam judiciais ou não, mas que envolvem diversos atores que podem conjuntamente construir uma solução consensuada.

Cada vez mais os problemas complexos, notadamente na área dos direitos fundamentais (p. ex. educação, moradia, saúde) tem exigido uma atuação conjunta, estratégica e harmoniosa entre as diversas instituições interessadas na resolução do problema, de modo interinstitucional. A questão da educação infantil transcende o interesse individual, porque busca a reestruturação da política pública, carecendo de uma decisão judicial estruturante, que em geral, envolve diversos atores. 
Anotamos que não existem instrumentos reguladores, de amplitude geral, normatizando a forma ou permissão de atuação conjunta entre instituições do sistema de justiça. Na prática o que acontece são celebrações de acordos pontuais, com objeto ou intenções definidas para consecução de uma finalidade em comum. Assim, as instituições pouco se conversam e tem conhecimento das ações e práticas que estão sendo adotadas por cada instituição para enfrentamento das políticas públicas. A falta de comunicação provoca, inclusive, atuação dúplice nas instituições. Muitas vezes, por exemplo, um usuário pede auxílio na Defensoria e no Ministério Público para tratar da mesma questão, o que pode gerar providências desnecessárias e até mesmo contraditórias.

Além disso, internamente, verificou-se que a Defensoria tem dificuldade de apontar seu representante nessa nova maneira de atuar, justamente por não possuir as defensorias de tutela coletiva e levando em conta que os núcleos temáticos assoberbados de trabalho, contam com coordenadores com mandato temporário.

Causa dificuldade, ainda, o fato de a Defensoria não possuir compilação de dados estatísticos para colaborar no planejamento do melhor enfrentamento dos problemas. Por derradeiro, constatou-se que o empenho nas construções interinstitucionais acaba sendo esvaziado ou, pelo menos, não tem seu aproveitamento maximizado, na medida em que não há uma divulgação e uma publicidade para a carreira acerca das atividades, acordos ou combinações celebradas nestas ações dialógicas. Sem disseminação no interior da carreira, os ajustes deixam de ser replicados por seus membros.

Diante do apresentado, entendemos que um conjunto de medidas devem ser implementadas concomitantemente, para transformar a situação averiguada, cujos tópicos relacionamos abaixo, sem que estejam em ordem de implementação, nem em ordem de prioridade:

a) Libertar-se do modelo herdado da antiga Procuradoria de Assistência Judiciária, calcado no ajuizamento de ações individuais, política interna definida para enfrentamento do déficit de vagas que garante o acesso à educação infantil. A atuação da Defensoria Pública quanto à defesa do direito ao acesso à educação infantil é desarticulada internamente e o desenho institucional de atendimento é fragmentado no Município de São Paulo, fazendo com que o usuário passe por diversos locais de atendimentos, com 
defensores diversos. Portanto, é preciso uma organização institucional que deixe de apostar na judicialização maciça das políticas públicas, dando ênfase e importância para as vias extrajudiciais, especialmente os arranjos interinstitucionais;

b) Realizar um estudo aprofundado nas diversas comarcas identificando os locais de maior problema na questão educacional, para embasar a criação de um planejamento de expansão institucional a médio e longo prazo para alocação de defensores com atribuição na temática da infância e juventude nestes locais. Além disso, reforçar o número de membros na carreira que tenham estas atribuições, porquanto hoje são pouco mais de $10 \%$ de toda a carreira que atuam nesta temática, o que impossibilita o enfrentamento da política com a energia que o problema exige;

c) Criação das defensorias regionais de educação, que seriam centros de atuação de defensores com atribuição exclusiva na temática da infância e juventude. Tais defensorias teriam a expertise de se aprofundar verticalmente no tema, conhecendo a rede como um todo, cujos membros teriam que se substituir entre si em caso de ausências e vacâncias, de modo que garantiria uma maior continuidade das políticas adotadas por tais centros. A regionalização também criaria melhores resultados, na medida em que a cobertura de locais de atuação extra comarca permitiriam um melhor enfrentamento da questão macro da política educacional, que não observa limites territoriais;

d) Sem prejuízo da criação das Defensorias regionais de educação, é de rigor e urgente a efetiva implementação das defensorias de tutelas coletivas em todas as unidades. Quer dizer, imperioso colocar em prática a já editada Deliberação CSDP no 139, que estabelece as defensorias de tutela coletiva. Com isso, seriam identificadas, finalmente, as Defensorias legitimadas para atuação por meio de tutelas coletivas. Atualmente a atuação por meio de tutelas coletivas encontra-se relegada ao voluntarismo de seus membros. Tanto que a quantidade de ações civis públicas manejadas é ínfima;

e) Superação do atual modelo de núcleo especializado temático da infância e juventude, que tem uma natureza híbrida, composta de dois coordenadores afastados e de 15 membros colaboradores em sistema de mandato temporário. $\mathrm{O}$ núcleo - em que pese seu trabalho excepcional, com afinco de seus coordenadores, que deve ser reconhecido acima de qualquer crítica - não dispõe de estrutura material 
e humana para realização do seu mister. Além disso, ausente corpo técnico que possa auxiliar na instrução das ações coletivas. $\mathrm{O}$ desenho atual no núcleo possibilita uma atuação descompromissada e sem um planejamento estratégico de atuação. O volume de trabalho sobrecarrega os coordenadores que realizam atos de gestão e execução ao mesmo tempo. Por outro lado, os núcleos situados na capital não tem fôlego para cravar suas raízes de auxílio nas comarcas da região metropolitana e interior, prestando tal apoio de forma esporádica e pontual. A criação de centros de apoio técnicos que possam efetivamente subsidiar o Defensor no procedimento preparatório da ação civil pública são de extrema importância. O formato institucional atual do Núcleo especializado da Infância e Juventude dificulta que este realize suas funções, ou melhor, suas competências normativas, como de: estimular o intercâmbio permanente entre os Defensores Públicos, perseguindo o aperfeiçoamento das atribuições institucionais e a uniformidade dos entendimentos ou teses jurídicas. Não há uma efetiva promoção do diálogo intrainstitucional sobre o acesso ao direito à educação infantil a partir da concepção do litígio estratégico; estimular o intercâmbio com entidades públicas e privadas, bem como representar a instituição perante conselhos e demais órgãos colegiados; prestar auxílio aos órgãos de atuação e de execução da Defensoria Pública estadual; a de reunir e expedir informações técnicojurídicas;

f) Construção de um planejamento estratégico de atuação na área da infância e juventude, através de adoção de coordenadas estratégicas de atuação, sem afrontar a independência funcional dos Defensores, mas possibilitando nortear a atuação institucional com unicidade de ação. As coordenadas seriam construídas de forma democrática, com intervenção dos órgãos legitimados e com debate juntamente com os membros atuantes na temática, de modo a avalizar uma construção conjunta. A harmonização do princípio institucional e da garantia da independência funcional deve advir da efetiva compreensão da Defensoria Pública enquanto instituição voltada à concretização de direitos fundamentais ideias diretrizes - no caso, em verdade, de normas constitucionais dirigentes;

g) Repensar os atuais instrumentos de participação coletiva e intervenção da sociedade civil em geral, no planejamento institucional, de modo a tornar útil, por exemplo, as intervenções nas Conferências Estaduais que justamente comporão o Plano 
Anual de Atuação da Defensoria. Entendemos imprescindível a implementação de novos arranjos institucionais que consignem procedimentos democráticos de diálogo, deliberação e ação, guardando relação com a modificação de paradigma da obrigatoriedade de reagir às demandas, para o de planejamento participativo. Suplantar o cenário de atuação repetitiva e mecanizada para uma mais inteligente, concatenada que alcancem melhores resultados;

h) Fomentar o contínuo debate interinstitucional por meio das escolas de cada instituição (escola da Defensoria, da Magistratura, do Ministério Público), viabilizando uma efetiva troca de informações e experiências que culminaram, consequentemente, numa atuação mais entrosada entre os agentes do sistema de justiça para obtenção dos fins em comuns. Faz-se imprescindível a revisão da condução interna pela Defensoria das ações judiciais e extrajudiciais em casos de direitos difusos e coletivos a partir do contexto de litígio estratégico, tendo em vista a natureza plurilateral dos conflitos de justiça distributiva;

i) Aprimorar a compilação de dados estatísticos na Defensoria, para que as informações armazenadas permitam auxiliar no planejamento institucional, na medida em que exibirá as deficiências em diversos pontos de atuação, que carecem de melhorias;

Obviamente, ao cabo deste trabalho não pretendíamos apresentar um projeto completo e acabado do novo desenho institucional da Defensoria Pública. O que seria de extrema pretensão de nossa parte. Contudo, verificada que da indagação inicial confirmouse a resposta negativa, existe amplo espaço de aperfeiçoamento institucional para que a Defensoria Pública tenha efetivas condições de concretizar os ditames constitucionais do direito à educação. Embora tenhamos assinalado um grupo de medidas que entendemos premente para caminhar no sentido deste aperfeiçoamento, faz-se imprescindível consignar que outras tantas não foram possíveis esgotar neste trabalho. Isto porque, ao longo desta tese, além da hipótese central, outras perguntas surgiram enquanto buscávamos as respostas para a questão principal.

Uma das mais difíceis seria: a Defensoria Pública consegue efetivamente organizar-se de forma institucional, para concretizar os ditames constitucionais educacionais (ainda que diante da implementação das mudanças sugeridas) com o reduzido quadro de Defensor que a instituição dispõe? Isto, pois, um dos maiores entraves está na 
quantidade de membros da carreira para fazer frente aos desafios. Talvez o indicativo positivo ou negativo desta resposta somente apareça após a efetiva implementação de algumas providências na atual organização institucional, até para avaliar se as mesmas resultariam em mudanças no cenário. Neste sentido, de se indagar: o Poder Público irá cumprir o artigo 98 do ADCT, acrescido pela Emenda Constitucional 80 de 2014, consistente na universalização do acesso à Justiça até 2022, devendo alocar defensores públicos em todas as comarcas (unidades jurisdicionais) do país?

Uma segunda indagação que poderá ser levada adiante em estudo futuro mais aprofundando, partindo das premissas já expostas neste trabalho seria desvendar qual o efetivo papel dos núcleos temáticos especializados da Defensoria? Órgão efetivamente execução? Órgão de apoio ao Defensor? Deveria existir um núcleo para cada direito social fundamental? Outra possibilidade de estudo verticalizado consistiria na verificação dos limites da independência funcional dos Defensores, especialmente em cotejo ao interesse público coletivo. Até que ponto a independência funcional pode ser garantia absoluta do Defensor? Entretanto, além destas questões outras ficaram sem resposta. Qual seria a função da Escola da Defensoria Pública no acolhimento, treinamento e permanente capacitação dos Defensores Públicos, de modo a garantir que tenham uma formação de ingresso na carreira concatenada com a filosofia institucional, e que promova a contínua reflexão de suas atribuições? Como criar mecanismos para que a Defensoria Pública possa contribuir ativamente no processo de formação das políticas públicas governamentais, de maneira "preventiva", uma vez que detém expertise dos problemas da sociedade em geral? Como alinhar uma política de atuação harmônica e com comunhão de desígnios entre a Defensoria e os diversos prestadores de serviços de assistência judiciária indireta, de modo a garantir a mesma qualidade de serviço aos jurisdicionados? Existe diferença da efetivação da educação infantil nos locais em que a Defensoria se encontra atuante em comparação às comarcas em que a Defensoria não se encontra instalada, cuja atuação se dá pelos conveniados? Em que medida a Deliberação do Conselho Superior de $\mathrm{n}^{\mathrm{o}} 144$ que dispôs que em cada comarca onde estiver instalada unidade da Defensoria deverá prioritariamente ser promovido o atendimento integral à área da Infância e Juventude, em conformidade com as atribuições institucionais da Defensoria Pública do Estado e a indicação de advogados conveniados com a Defensoria Pública será permitido apenas nas comarcas onde não houver unidade da Defensoria Pública está efetivamente sendo cumprida? 
É inegável o avanço e as conquistas obtidas pela Defensoria Pública do Estado de São Paulo em tão pouco tempo de existência. Considerando se tratar de instituição que ainda desabrocha, pois conta com apenas 13 anos desde a promulgação de sua Lei Complementar que culminou no início de sua existência, há muito que se festejar. Entretanto, diversas questões institucionais carecem de aprimoramento para que a Defensoria Pública do Estado de São Paulo possa desincumbir-se, com eficiência, das obrigações constitucionais postas para a concretização do direito à educação infantil. As providências são complexas. Dependem de material humano, recursos e vontade política. Mas, certamente com o afinco e dedicação de seus membros, que não descansam, com a colaboração das outras instituições igualmente incumbidas da concretização dos direitos fundamentais sociais, as metas poderão ser alcançadas. 


\section{REFERÊNCIAS}

ABRAMOVICH, Victor e COURTIS, Christian. El umbral de la ciudadanía - El significado de los derechos sociales en el Estado social constitucional. Buenos Aires: Editores del Puerto, 2006.

AÇÃO EDUCATIVA. Boletim Eletrônico OPA - Informação pelo Direito à Educação, Ano V, Ed. 51, dezembro/janeiro, 2010.

ALEXY, Robert. Teoria dos Direitos Fundamentais. Tradução Virgilio Afonso da Silva da

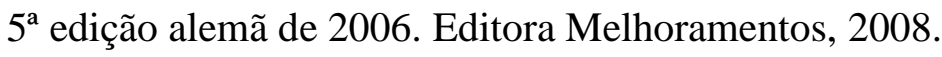

ALMEIDA, Dayse Coelho de. A fundamentalidade dos direitos sociais e o princípio da proibição do retrocesso. Inclusão Social, Brasília, v. 2, n.1, out.2006/mar.2007.

ARANTES, Rogério Bastos. Direito e política: o Ministério Público e a defesa dos direitos coletivos. Revista Brasileira de Ciências Sociais, v. 14, n. 39, 1999.

ARAUJO, LUIZ. O que muda com a aprovação da Emenda $\mathrm{n}^{\circ}$ 59? In: http://rluizaraujo.blogspot.com/2009/10/o-que-muda-com-aprovacao-da-emenda-n59.html. Acesso em 30 de julho de 2019.

ARENHART. Sérgio Cruz. Processo multipolar, participação e representação de interesses concorrentes. In: ARENHART, Sérgio Cruz; JOBIM, Marco Félix (org.). Processos estruturais. Salvador: JusPodivm, 2017.

Decisões estruturais no direito processual civil brasileiro. Revista de Processo, v. 225, 2013.

Processos estruturais no direito brasileiro: reflexões a partir do caso da ACP do carvão. Revista de Processo Comparado: RPC, v. 1, n. 2. 
ARNESEN, Erik Saddi. Educação e cidadania na Constituição Federal de 1988. Dissertação (Mestrado em Direito) - Faculdade de Direito, Universidade de São Paulo, São Paulo, 2010.

BARCELLOS, Ana Paula. Neoconstitucionalismo, direitos fundamentais e controle das políticas públicas. In: NOVELINO, Marcelo (org.). Leituras Complementares em Direito Constitucional. Direitos Humanos e Direitos Fundamentais. $3^{\mathrm{a}}$ edição. São Paulo: JusPODIVM, 2008.

BERCOVICI, Gilberto. Desenvolvimento e políticas públicas. In: BUCCI, Maria Paula Dallari (Org.). Políticas públicas: reflexões sobre o conceito. São Paulo: Saraiva, 2006.

BODIN, Jean. (1986), Les six livres de la République. Reimpressão da 12a edição (1593). Paris, Librarie Artheme Fayard.

BRITTO, Adriana. A evolução da Defensoria Pública em direção à tutela coletiva. In: SOUSA, José Augusto Garcia (coordenador). A Defensoria Pública e os processos coletivos. Comemorando a Lei Federal 11.448, de 15 de Janeiro de 2007.

BUCCI, Maria Paula Dallari. O conceito de política pública em direito. In: BUCCI, Maria Paula Dallari (Org.). Políticas públicas: reflexões sobre o conceito jurídico. São Paulo: Saraiva, 2006.

e VILARINO, Marisa Alves. A ordenação federativa da Educação brasileira e seu impacto sobre a formação e o controle das políticas públicas educacionais In Justiça pela qualidade na educação/ ABMP, Todos pela educação (organização). São Paulo: Editora Saraiva, 2013.

Fundamentos para uma teoria jurídica das políticas públicas. São Paulo: Saraiva, 2013.

Quadro de referência de uma política pública. Primeiras linhas de uma visão jurídico-institucional. Método: utilidade do quadro de referência para análise jurídica de 
políticas públicas. Texto aula pós graduação da faculdade de direito da universidade de São Paulo.

CAJUELLA, Fayola Sant' Anna. O acesso à justiça e o direito à educação infantil: um estudo sobre a atuação da Defensoria Pública do Estado de São Paulo / Fayola Sant'Anna Cajuella. 2016, dissertação de mestrado, FGV.

CALLEGARI, Cesar. A judicialização da Educação Infantil no Brasil. In: Reflexões sobre Justiça e Educação, organização Todos pela Educação. Editora Moderna, $1^{a}$ edição. São Paulo, 2017.

O financiamento da educação básica. In: Justiça pela qualidade na educação. ABMP, Todos pela educação (organização) - São Paulo: Saraiva, 2013.

CAPELLA, Ana Cláudia N. Perspectivas teóricas sobre o processo de formulação de políticas públicas. In Políticas Públicas no Brasil (Gilberto Hochman, Marta Arretche e Eduardo Marques, orgs.). Rio de Janeiro: Editora Fiocruz, 2007.

CAPPELLETTI, Mauro; GARTH, Bryant. Acesso à justiça. Porto Alegre: Fabris, 1988.

CARDOSO, Luciana Zaffalon Leme SADEK, Maria Tereza Aina (Coord.). Relatório da Pesquisa de Satisfação dos Usuários e Usuárias dos Serviços da Defensoria Pública do Estado de São Paulo. São Paulo, 2012.

CARREIRA, Denise. Plano de educação da cidade: um direito da população de São Paulo. Educação e desigualdades na cidade de São Paulo. São Paulo: Ação Educativa, 2013, Disponível em: <http://www.acaoeducativa.org/portal/images/stories/pdfs/educ_desig.pdf >. Acesso em 25 abril 2019.

CATHARINA. Alexandre de Castro. A construção dialógica dos precedentes judiciais: breves reflexões sobre democratização do processo judicial. Revista eletrônica direito e sociedade. In: https://revistas.unilasalle.edu.br/index.php/redes/article/view/2272. Acesso em 14 de agosto de 2019. 
CEBRIAN, Alexandre; GONÇALVES, Victor. Direito Processual Penal Esquematizado, São Paulo: Saraiva, 2012.

CHAYES, Abram. The Role of the judge in public law litigation. Harvard Law Review, vol. 89, n. 7, 1976.

COMPARATO, Fábio Konder. Ensaio sobre o juízo de constitucionalidade de políticas públicas. Revista dos Tribunais 737, 1997.

CORGOSINHO, Gustavo. Defensoria Pública: princípios institucionais e regime jurídico, Belo Horizonte: Dictum, 2009.

CORRÊA, Luiza Andrade. A judicialização da política de educação infantil no Tribunal de Justiça de São Paulo. São Paulo: USP / Faculdade de Direito, 2014.

COSTA, Nelson Nery. Manual do Defensor Público, Rio de Janeiro, GZ editora, 2010.

COUTINHO, Angela Scalabrin; SILVEIRA, Adriana Aparecida Dragone. As políticas de priorização para o acesso ao direito à educação infantil em creches. In Trama Interdisciplinar, São Paulo, v.7, n. 2, maio/ago.2016.

CUNHA, Luciana Gross Siqueira. O acesso à justiça e a assistência jurídica em São Paulo. In: AINA, Maria Tereza Sadek (Org.). Acesso à justiça. São Paulo: Fundação Konrad Adenauer, 2001, p. 199.

; FEFERBAUM, Marina. Repensando o papel da Defensoria Pública: uma nova estratégia para o aprimoramento da cidadania. In: RÉ, Aluísio Iunes Monti Ruggerri (Org.). Temas aprofundados da Defensoria Pública. São Paulo: JusPodivm, 2014. v. 2.

CUNHA JÚNIOR, Dirley da. A efetividade dos direitos fundamentais sociais e a reserva do possível. Leituras Complementares em Direito Constitucional. Direitos Humanos e Direitos Fundamentais. $3^{\text {a }}$ edição. São Paulo: JusPODIVM, 2008. 
CURY, C. R. J. Por um sistema nacional de educação. São Paulo: Moderna, 2010.

DA SILVA, José Afonso. Comentário Contextual à Constituição. 9a ed. São Paulo: Malheiros, 2014.

Curso de direito constitucional positivo, $6^{\text {a }}$ edição. São Paulo: Revista dos Tribunais, 1990.

DAL POZZO, Antonio Araldo Ferraz. A. Atuação extrajudicial do Ministério Público: dever ou faculdade de agir? In: RIBEIRO, C. V. A. (Org.). Ministério Público: reflexões sobre princípios e funções institucionais. São Paulo: Atlas, 2010.

DECASTILHO, Ela Wiecko Volkmer. "Direito à Educação e o Ministério Público". In: Ação Educativa. Boletim OPA - Informação pelo Direito à Educação, Ano III, n. 32, janeiro de 2007.

DI DIO, R. A. T. Contribuição à sistematização do direito educacional. Taubaté: Editora Universitária, 1982.

DIDIER JR, Fredie; ZANETI JR., Hermes. Curso de direito processual civil, v. 4, Bahia: Juspodivm, 2007.

., Hermes; OLIVEIRA, Rafael Alexandria. Notas sobre as decisões estruturantes. In: ARENHART, Sérgio Cruz; JOBIM, Marco Félix (org.). Processos estruturais. Salvador: JusPodivm, 2017.

DINAMARCO, Cândido. Fundamentos do Processo Civil Moderno, $3{ }^{a}$ ed., São Paulo: Malheiros, 2000.

DO VAL, Juliana. “O direito à educação no ordenamento jurídico brasileiro” Disponível em https://www.defensoria.sp.def.br/dpesp/Default.aspx?idPagina=5212. Acesso em 16 de maio de 2019. 
DUARTE, Clarice Seixas. Direito público subjetivo e políticas educacionais. São Paulo em Perspectiva, São Paulo, vol. 18, n.2, 2004.

DWORKIN, Ronald. Law's Empire. Cambrige (Mass): Harvard Univerty Press, 1986. Taking Rights Seriously. Cambrige, Mass.: Harvard University Press, 1977. Tradução Nelson Boeira. Levando os direitos a sério. São Paulo: Martins Fontes, 2002.

ESTEVES, Diogo; ROGER, Franklyn. Princípios Institucionais da Defensoria Pública. Rio de Janeiro: Forense, 2014.

FACHIN, Melina Girardi; GONÇALVES, Marcos Alberto Rocha. De fora, de cima e de baixa - todos os sentidos da dignidade do discurso dos direitos. Revista Brasileira de direitos e garantias fundamentais. Curitiba, v. 2, n. 2, jul./dez. 216.

; SHINEMANN, Caio Cesar Bueno. Decisões estruturantes na jurisdição constitucional brasileira: critérios processuais da tutela jurisdicional de direitos prestacionais. Journal of Institucional Studies 1. Revista Estudos Institucionais, Vol. 4, 1, $215,2018$.

FARIA, José Eduardo. O sistema brasileiro de Justiça: experiência recente e futuros desafios. Estudos Avançados, v. 18, n. 51, 2004.

FENSTERSEIFER, Tiago. Defensoria Pública, direito fundamental à saúde, mínimo existencial, ação civil pública e controle judicial de políticas públicas. In Revista da Defensoria Pública (publicação EDEPE), ano 1, VOL. 2, jul-dez. 2008.

FERRAZ, Octávio Luiz Motta. Brazil: health inequalities, rights, and courts: the social impact of the "judicialization of health". In: YAMIN, Alicia Ely; GLOPPEN, Siri (eds.). Litigating health rights: can courts bring more justice to health?. Cambridge, Mass.: Harvard Law School, 2011 .

FIANI, Ronaldo. Arranjos institucionais e desenvolvimento: o papel da coordenação em estruturas híbridas. Rio de Janeiro, março de 2013. 
FILGUEIRA, Yasmin Von Glehn Santos; GONÇALVES, Gabriella Vieira Oliveira; BRITO, Lany Cristina Silva (Org.). IV Diagnóstico da Defensoria Pública no Brasil. Brasília: Ministério da Justiça, Secretaria de Reforma do Judiciário, 2015. Disponível em: $<$ https://www.anadep.org.br/wtksite/downloads/iv-diagnostico-da-defensoria-publica-nobrasil.pdf > . Acesso em25 de julho de 2018.

FISS, Owen. To make the Constitution a living truth: four lectures on the structural injunction. In: ARENHART, Sérgio Cruz; JOBIM, Marco Félix (org.). Processos estruturais. Salvador: JusPodivm, 2017.

FULLER, Lon. The Forms and Limits of Adjudication, Harvard Law Review, v. 92, $\mathrm{n}^{\circ}$ 02, 1976.

GALANTER, Marc. Why the 'haves' come out ahead? Law and Society Review. v. 9, 1974.

GALLIEZ, Paulo. Defensoria Pública - Legislação. $2^{\text {a }}$ Edição. São Paulo: Lumen Juris, 2002.

. A Defensoria Pública, o Estado e a Cidadania. São Paulo: Lumen Juris, 2001.

. Princípios Institucionais da Defensoria Pública. São Paulo: Lumen Juris, 2007.

GARAVITO, Cézar Rodrigues. Beyond the courtroom: the impact of judicial activism on socioeconomic rights in Latin American. Texas Law Review, vol. 89, 2011.

GODOY, Miguel Gualano de. Devolver a constituição ao povo: crítica à supremacia judicial e diálogos institucionais. Belo Horizonte: Fórum, 2017.

GOMES, Marcos Vinicius Manso Lopes. Direitos Humanos e Princípios Institucionais da Defensoria Pública. Coleção Defensoria Pública - Ponto a Ponto. São Paulo. Editora Saraiva, 2018. 
GOTTI, Alessandra. Direitos sociais: fundamentos, regime jurídico, implementação e aferição de resultado. São Paulo: Saraiva, 2012.

Um retrato da judicialização da educação Básica no Brasil. In: Reflexões sobre Justiça e Educação. Organização Todos pela Educação. São Paulo: Editora Moderna, 2017.

e XIMENES, Salomão B. Opinião legal: "Litígio estrutural - déficit de vagas em creches e pré-escolas no município de são Paulo - multiplicidade de ações judiciais estratégia de exigibilidade alternativa”, confeccionado para a Ação Educativa.

GRACIANO, Mariângela; MARINHO, Carolina; FERNANDES, Fernanda. As demandas judiciais por educação na cidade de São Paulo. In: HADDAD, Sérgio; GRACIANO, Mariângela (Org.). A educação entre os direitos humanos. Campinas: Autores Associados, 2006.

GRINOVER, Ada Pellegrini; WATANABE, Kazuo. O Controle jurisdicional de políticas públicas, in O Controle jurisdicional de políticas públicas (orgs. Ada Pellegrini Grinover e Kazuo Watanabe), Rio de Janeiro: Forense, 2011.

; WATANABE, Kazuo; LUCON, Paulo Henrique dos Santos. Projeto de Lei 8.058/2014 e o controle jurisdicional de políticas públicas. Artigo.

FREIRE JÚNIOR, Américo Bedê. O controle judicial de políticas públicas. São Paulo: Editora Revista dos Tribunais, 2005.

HAURIOU, Maurice. Teoria da Instituição e da Fundação: ensaio de vitalismo social. Porto Alegre: Sergio Antonio Fabris Ed., 2009.

HERRLEIN JR., Ronaldo. A construção de um estado democrático para o desenvolvimento no século XXI, in Capacidades Estatais e Democracia. Arranjos Institucionais de Políticas Públicas (Alexandre Gomide e Roberto Rocha Pires, orgs.). Brasília: IPEA, 2014 
HOMMA, Fernanda Lissa Fujiwara. Artigo publicado para o Anais do Simpósio Brasileiro de Processo Civil, íntegra disponibilizada em http://abdconst.com.br/anaiscivil/Fernanda\%20Lissa\%20Fujiwara\%20Homma.pdf. Acesso em 16 de janeiro de 2019.

IPEA - INSTITUTO DE PESQUISA ECONÔMICA APLICADA, Justiça infantojuvenil: situação atual e critérios de aprimoramento. Relatório de Pesquisa. Brasília: Ipea, 2011.

James M Apud Altman, "Implementing a Civil Rights Injunction: a Case Study of NAACP v. Brennan", Columbia Law Review 78:739, 1978.

JOBIM, Marco Félix. Medidas estruturantes: da Suprema Corte estadunidense ao Supremo Tribunal Federal. Porto Alegre: Livraria do Advogado, 2013.

LAYCOCK, Douglas. The death of the irreparable rule. New York: Oxford University Press, 1991.

LENZA, Pedro. Direito Constitucional Esquematizado. 18 edição. São Paulo: Editora Saraiva, 2014.

LIBERATI, Wilson Donizeti Liberati (org.). Direito à educação: uma questão de justiça. São Paulo: Malheiros, 2004.

LIMA, Frederico Rodrigues Viana de. Defensoria Pública. $3^{\text {a }}$ ed. Salvador: Juspodivm, 2014.

MARINHO, Carolina. Justiciabilidade dos Direitos Sociais: Análise de Julgados do Direito à Educação sob o Enfoque da Capacidade Institucional. Dissertação de Mestrado apresentada na Faculdade de Direito da USP. São Paulo, 2009.

MARINONI, Luiz Guilherme, e ARENHART, Sergio Luiz. Curso de Processo Civil V.2. RT. 2013. 
MARQUES NETO, Floriano de Azevedo. Entre independência institucional e neopatrimonialismo: a distorção da doutrina do "Promotor natural". In: RIBEIRO, C. V. A. (Org.). Ministério Público: reflexões sobre princípios e funções institucionais. São Paulo: Atlas, 2010.

MARTINES JUNIOR, Eduardo. Educação, Cidadania e Ministério Público: o art. 205 da Constituição e sua abrangência. Tese (Doutorado em Direito). São Paulo: PUC/SP, 2006.

MAZZILLI, Hugo Nigro. Ministério Público. São Paulo: Damásio de Jesus, 2004.

MEYER, Emílio Peluso Neder. Decisão e jurisdição constitucional: críticas às sentenças intermediárias, técnicas e efeitos do controle de constitucionalidade em perspectiva comparada. Rio de Janeiro: Lumen Juris, 2017.

MORAES, Alexandre de. Direito constitucional. 19. ed. São Paulo: Atlas, 2006.

. Direitos Humanos Fundamentais e Democracia. Jurídico Atlas. Periódico, Novembro de 1997.

O Avanço na efetivação dos direitos fundamentais em 25 anos de Constituição de 1988. Revista Consulex, A.7, n. 401, 2013.

MORAES, Guilherme Peña de. Instituições da Defensoria Pública. São Paulo: Malheiros, 1999.

MORAES, Sílvio Roberto Mello. Princípios Institucionais da Defensoria Pública, Rio de Janeiro: Revista dos Tribunais, 1995.

MUNIZ, Cibele Cristina Baldassa. Dos direitos sociais e sua defesa pela Defensoria Pública. In: HADDAD, Eneida Gonçalves de Macedo. A Defensoria Pública do Estado de São Paulo: por um acesso democrático à Justiça. São Paulo: Letras Jurídicas, 2011.

OLIVEIRA, Eugênio Pacelli. Curso de Processo Penal, São Paulo: Atlas, 2012. 
OLIVEIRA, Camila Torres. Financiamento público da educação básica no Brasil - uma análise do Fundeb - monografia apresentada ao departamento de economia da universidade de Brasília. http://mecsrv04.mec.gov.br/sef/fundef/funf.shtm, acesso em 10.06.2018.

OLIVEIRA, Romualdo Portela de. O direito à educação. In: OLIVEIRA, Romualdo Portela de, ADRIÃO, Theresa (orgs.). Gestão, financiamento e direito à educação. Análise da LDB e Constituição Federal. São Paulo: Xamã, 2001.

O direito à educação na Constituição Federal e seu restabelecimento pelo sistema de justiça. Revista Brasileira de Educação, n. 11, maio/ago., 1999.

OSNA, Gustavo. Nem "tudo", nem "nada" - decisões estruturais e efeitos jurisdicionais complexos. In: ARENHART, Sérgio Cruz; JOBIM, Marco Félix (org.). Processos estruturais. Salvador: JusPodivm, 2017.

PAIVA, Caio. Além de um princípio, independência funcional é garantia do defensor. Artigo no Conjur, de 16 de junho de 2015. Disponível em https://www.conjur.com.br/2015-jun-16/tribuna-defensoria-alem-principio-independenciafuncional-garantia-defensor Acessado em 15.06.2019.

PAIVA, R. G. Direito educacional: do fato ao direito. In: TRINDADE, A. (Coord.). Direito educacional em uma ótica sistêmica. Curitiba: Juruá, 2010.

PIOVESAN; Flávia; VIEIRA, Renato Stanziola. Araucaria. Revista Iberoamericana de Filosofia, Politica y Humanidades, n. 15, abr. 2006.

Justiciabilidade dos direitos sócias e econômicos: Desafios e Perspectivas In Direitos Fundamentais Sociais. Coordenação J.J. Gomes Canotilho, Marcus Orione Gonçalves Correia, Érica Paula Barcha Correia. São Paulo: Editora Saraiva, 2010.

- Direitos Humanos, o Princípio da Dignidade Humana e a Constituição

Brasileira de 1988. In: Revista do Instituto de Hermenêutica Jurídica. (Neo) Constitucionalismo. Ontem os Códigos, hoje as Constituições. Porto Alegre: Instituto de Hermenêutica Jurídica. n. 2, 2004. 
RANIERI, Nina Beatriz Stocco. O Estado Democrático de Direito e o sentido da exigência de preparo da pessoa para o exercício da cidadania, pela via da educação. Tese (LivreDocência) - Faculdade de Direito, Universidade de São Paulo, 2009.

O novo cenário jurisprudencial do direito à educação no Brasil: o ensino domiciliar e outros casos no Supremo Tribunal Federal. DOSSIÊ: Homeschooling e o Direito à Educação. Caderno proposições. V. 28, N. 2 (83) | Maio/Ago. 2017.

O Supremo Tribunal Federal e o direito à educação: a promoção Indireta dos princípios e normas internacionais. In: AMARAL JUNIOR, Alberto do; JUBILUT, Liliana Lyra. (Org.). O STF e o direito Internacional dos direitos humanos. São Paulo: Quartier Latin, 2009.

. Panorama da judicialização do direito à Educação no Supremo Tribunal Federal entre 2000 e 2015. In: Reflexões sobre justiça e educação/Organização Todos pela educação, Editora Moderna - $1^{\text {a }}$ edição - São Paulo: Moderna, 2017.

; vários autores. O direito educacional no sistema jurídico brasileiro. In: ABMP, Todos pela Educação. (Org.). Justiça pela Qualidade na Educação. 1 ed. São Paulo: Editora Saraiva, 2013, v. 1.

. A Cátedra Unesco de Direito à Educação da Faculdade de Direito: Democracia, cidadania e direito à educação. Revista da Faculdade de Direito, Universidade de São Paulo, São Paulo, v. 108, nov. 2013a. Disponível em: <http://www.revistas.usp.br/rfdusp/article/view/67990>. Acesso em: 19 dez. 2017.

Educação obrigatória e gratuita no Brasil: um longo caminho, avanços e perspectivas In: Direito à educação e direitos na educação em perspectiva interdisciplinar / organizado por Nina Beatriz Stocco Ranieri e Angela Limongi Alvarenga Alves. - São Paulo: Cátedra UNESCO de Direto à Educação/Universidade de São Paulo (USP), 2018. $520 \mathrm{p}$. 
REIS, Gustavo Augusto Soares dos; JUNQUEIRA, Gustavo Octaviano Diniz; ZVEIBIL, Daniel Guimarães. Comentários à Lei da Defensoria Pública. São Paulo: Saraiva, 2013.

RIBEIRO, Lauro Luiz Gomes. Direito Educacional - Educação Básica e Federalismo São Paulo: Quartier Latin, 2009.

RIZZARDI, Maíra Martinelli. Os Ciclos de Conferências da Defensoria Pública do Estado de São Paulo: controle e participação social. 2015. Dissertação (Mestrado em Direito e Desenvolvimento) - Escola de Direito de São Paulo da Fundação Getulio Vargas, São Paulo.

ROCHA, Amélia Soares da. Defensoria Pública: fundamentos, organização e funcionamento. São Paulo: Atlas, 2013.

ROSENBERG, Gerald N. The hollow hope: can Courts bring about social change? 2 ed., Chicago: University of Chicago Press, 2008.

ROSEMBERG, Fúlvia. Sísifo e a educação infantil brasileira. Pró-posições, v. 14, n.1, jan./abr. 2003. Disponível em: http://proposicoes.fe.unicamp.br/proposicoes/textos/40artigos-rosemberg-pdf. Acesso em: set. 2017.

RUGGERI RÉ, Aluísio Iunes Monti. Manual do Defensor Público - Teoria e Prática. Salvador: Juspodivm, 2013.

SALLES, Carlos Alberto de. Duas Faces de Proteção Judicial dos direitos sociais no Brasil In: As Grandes Transformações do Processo Civil Brasileiro - Homenagem ao Professor Kazuo Watanabe. SALLES, Carlos Alberto de (coord.) - São Paulo - São Paulo: Quartier Latin, 2009.

SARMENTO, Daniel; SOUZA NETO, Claudio Pereira, (orgs.). Direitos Sociais: Fundamentos, Judicialização e Direitos Sociais em espécie. Rio de Janeiro: Lumen Juris, 2008. 
SCHUBSKY, Cássio. Advocacia pública: apontamentos sobre a história da Procuradoria Geral do Estado de São Paulo. $1^{\text {a }}$ ed. São Paulo: Imprensa Oficial do Estado de São Paulo, 2008.

SECCHI, Leonardo. Políticas Públicas - Conceitos, Esquemas de Análise, Casos Práticos. São Paulo: Cengage Learning, 2012.

SILVA, João Paulo Faustinoni e. Ministério Público e a defesa do direito à educação: subsídios teóricos e práticos para o necessário aperfeiçoamento institucional. Dissertação de mestrado. São Paulo: USP/Faculdade de Direito, 2018.

SILVA, Virgílio Afonso da. O Judiciário e as políticas públicas: entre transformação social e obstáculo à realização dos direitos sociais. In: SOUZA NETO, Cláudio Pereira de; SARMENTO, Daniel (Org.). Direitos Sociais: fundamentos, judicialização e direitos sociais em espécie. Rio de Janeiro: Lumen Juris, 2008.

SILVEIRA, Adriana Aparecida Dragone. A exigibilidade do direito à educação básica pelo Sistema de Justiça: uma análise da produção brasileira do conhecimento. Rev. Brasileira de Política e Avaliação da Educação, v.24, n.3, set./dez., 2008.

. O direito à educação de crianças e adolescentes: análise da atuação do Tribunal de Justiça de São Paulo (1991 - 2008). 2010. 303 p. Tese de Doutorado. Faculdade de Educação. USP.

. Atuação do Tribunal de Justiça de São Paulo com relação ao direito de crianças e adolescentes à educação. Revista Brasileira de educação, v. 17, 2012.

SIQUEIRA, Julio Pinheiro Faro Homem de. Da reserva do possível e da proibição de retrocesso social. Revista do Tribunal de Contas do Estado de Minas Gerais, vol. 76, n. 3, jul./ago./set. 2010.

SOARES, Thais. A atuação da Defensoria Pública do Estado de São Paulo: a construção de um modelo inovador. In: HADDAD, Eneida Gonçalves de Macedo. A Defensoria Pública 
do Estado de São Paulo: por um cesso democrático à Justiça. São Paulo: Letras Jurídicas, 2011.

SOUSA, José Augusto Garcia de. 50 atuações coletivas da Defensoria Pública: um estudo empírico atento aos "consumidores" do sistema de justiça. In: RÉ, Aluisio Iunes Monti Ruggeri (Org.). Temas aprofundados Defensoria Pública. Salvador: JusPodivm, 2014. v. 1.

SOUZA NETO, Cláudio Pereira. Deliberação Pública, Constitucionalismo e Cooperação Democrática, p. 79-112. In: SARMENTO, Daniel (org.). Filosofia e Teoria Constitucional Contemporânea, Rio de Janeiro: Editora Lúmen Júris, 2009.

STRECK, Lenio Luiz. O que é isto - decido conforme minha consciência? $5^{\mathrm{a}}$ ed. Porto Alegre: Livraria do Advogado Editora, 2015.

Verdade e consenso: Constituição, hermenêutica e teorias discursivas. $5^{\mathrm{a}}$ ed. São Paulo: Saraiva, 2014.

e LIMA, Martonio Mont'Alverne Barreto. Lei de Políticas Públicas é "Estado Social a golpe de caneta", Revista consultor Jurídico (Conjur), 10 de fevereiro de 2015.

E que o texto constitucional não se transforme em um latifúndio improdutivo... — uma crítica à ineficácia do Direito. In: SARLET, I. W. (Org.). O direito público em tempos de crise: estudos em homenagem a Ruy Ruben Ruschel. Porto Alegre: Livraria do Advogado, 1999.

SUNSTEIN, Cass. Social and Economic Rights? Lessons from South Africa. John M. Olin Program in Law and Economics Working Paper n. 124, 2001.

TEIXEIRA, Anísio. Educação é um direito, 2ª ed. Rio de Janeiro: Editora UFRJ, 1996.

TORRES, Ricardo Lobo. O mandado de injunção e a legalidade financeira. Revista de Direito Administrativo. Rio de Janeiro, 187:94-110, jan./mar. 1992. 
. O Direito ao Mínimo Existencial, Rio de Janeiro/São Paulo/Recife: Renovar, 2009

TUCCI, Rogério Lauria. Direitos e Garantias individuais no processo penal brasileiro. São Paulo: Saraiva, 1993.

VIEIRA, Oscar Vilhena; ALMEIDA, Eloísa Machado de. Direito, Educação e transformação. In: Associação brasileira de magistrados, promotores de justiça e defensores públicos da infância e da juventude e todos pela educação (Org.). Justiça pela qualidade na educação. São Paulo: Saraiva, 2013.

VIOLIN, Jordão. Protagonismo judiciário e processo coletivo estrutural: o controle jurisdicional de decisões política. Salvador: JusPodvm, 2013.

VITORELLI, Edilson. O devido processo legal coletivo: dos direitos aos litígios coletivos. São Paulo: Revista dos Tribunais, 2016.

XIMENES, Salomão Barros. Direito à qualidade na educação infantil: teoria e crítica. São Paulo: Quartier Latin do Brasil, 2014.

e RIZZI, Ester. Litigância estratégica para a promoção de políticas públicas: as ações em defesa do direito à educação infantil em São Paulo, In Justiça e Direitos Humanos: experiências de assessoria jurídica popular - Curitiba, PR: Terra de Direitos, 2010.

; GRINKRAUT, Ananda. Acesso à educação infantil no novo PNE: parâmetros de planejamento, efetivação e exigibilidade do direito. Cadernos Cenpec. volume 4, n.1, 2014.

YEAZELL, Stephen C. The ordinary and the extraordinary in institucional litigation. Harvard Law Review, vol. 93, n. 3, 1980.

ZAPATA, Fabiana Botelho, FRASSETO, Flávio Américo. Direitos da Criança e do Adolescente. São Paulo: Saraiva, 2016 - (Coleção Defensoria Pública: ponto a ponto). 


\section{Sites da internet}

<http://www.defensoria.sp.gov.br/dpesp/Default.aspx?idPagina=5619>. Acesso em: 26 ago. 2018.

<http://www.defensoria.sp.gov.br/dpesp/Default.aspx?idPagina=5619>. Acesso em: 10 abril 2019.

<http://www.defensoria.sp.gov.br/dpesp/Default.aspx?idPagina=5933>. Acesso em: 10 abril 2019.

<http://www.defensoria.sp.gov.br/dpesp/repositorio/0/documentos/confer\%C3\%Ancias/Ca derno\%20de\%20Propostas.pdf>. Acesso em: 10 abril 2019.

<http://www.defensoria.sp.gov.br/dpesp/repositorio/0/documentos/confer\%C3\%AAncias/ Monitoramento\%2010.04.2013.pdf>. Acesso em: 15 jun. 2019.

<http://www.defensoria.sp.gov.br/dpesp/Repositorio/0/Documentos/Norte-Oeste.pdf>. Acesso em: 19 out. 2019.

<http://www.defensoria.sp.gov.br/dpesp/Repositorio/0/Documentos/Norte-Oeste.pdf>. Acesso em: 15 nov. 2018.

$<$ http://www.defensoria.sp.gov.br/dpesp/Repositorio/0/Documentos/Sul.pdf >. Acesso em: 19 out. 2018.

$<$ http://www.defensoria.sp.gov.br/dpesp/Repositorio/0/Documentos/Sul.pdf >. Acesso em: 15 jun. 2019.

<http://www.defensoria.sp.gov.br/dpesp/Repositorio/0/Documentos/Sul.pdf>. Acesso em: 15 jun. 2019.

<http://www.defensoria.sp.gov.br/dpesp/repositorio/0/Monitoramento\%20I\%20C iclo.pdf>. Acesso em: 15 jun. 2019. 
<http://www.defensoria.sp.gov.br/dpesp/repositorio/0/Monitoramento\%20I\%20Ciclo.pdf (Material de apoio do II Ciclo de Conferências da DPE/SP). Acesso em: 15 jun. 2019.

https://www.defensoria.sp.def.br/dpesp/Conteudos/Materia/MateriaMostra.aspx?idItem=24 85\&idModulo=5010. Acesso em: 05 jul. 2018.

https://www.defensoria.sp.def.br/dpesp/Conteudos/Materia/MateriaMostra.aspx?idItem=90 6\&idModulo=5010. Acesso em: 05 jul. 2018.

https://www.defensoria.sp.def.br/dpesp/Default.aspx?idPagina=2868. Acesso em: 15 jun. 2019.

https://www.defensoria.sp.def.br/dpesp/Default.aspx?idPagina=2869. Acesso em: 15 jun. 2019.

https://www.defensoria.sp.def.br/dpesp/Default.aspx?idPagina=2877. Acesso em: 15 jun. 2019.

https://www.defensoria.sp.def.br/dpesp/Default.aspx?idPagina=3141. Acesso em: 15 jun. 2019.

https://www.defensoria.sp.def.br/dpesp/Default.aspx?idPagina=3200. Acesso em: 15 jun. 2019.

https://www.defensoria.sp.def.br/dpesp/Default.aspx?idPagina=5616. Acesso em: 15 jun. 2019.

https://www.defensoria.sp.def.br/dpesp/Default.aspx?idPagina=6242. Acesso em: 15 jun. 2019.

http://www.defensoria.sp.gov.br/dpesp/Default.aspx?idPagina=5619>. Acesso em: 10 abril 2019; 
http://www.defensoria.sp.gov.br/dpesp/repositorio/0/Expans\%C3\%A3o\%20da\%20DP\%20 tutela\%20coletiva.pdf>. Acesso em: 15 ago. 2017.

http://www2.defensoria.sp.gov.br/dpesp/Conteudos/Materia/MateriaMostra.aspx ?idItem=8 68\&idModulo=4947. Acesso em 03 de março de 2018.

<http://pne.mec.gov.br/images/pdf/pne_conhecendo_20_metas.pdf. Acesso em: 03 fev. 2019.

<http://pne.mec.gov.br/planos-de-educacao. Acesso em: 09 março 2019.

<http://portal.sme.prefeitura.sp.gov.br/Main/Noticia/Visualizar/PortalSMESP/Sao-Paulocria-parceria-com-Defensoria-Publica-para-reduzir-judicializacao-da-educacao1?fbclid=IwAR3zF-u_8IgglljqHKde6RR9msi9QoQL-Nzdp2L8C4ceOp1gnwfRrjHSNJk. Acesso em: 15 jun. 2019.

<http://portal.sme.prefeitura.sp.gov.br/Main/Page/PortalSMESP/Apresentacao. Acesso em: 01 abril 2019.

http://www.acaoeducativa.org.br/portal/images/stories/pdfs/peticaoinicialacp1.pdf $>$ Acesso em: 15 jun. 2019.

http://www.mpsp.mp.br/portal/page/portal/noticias/publicacao_noticias/2011/marco_2011/ MP\%20prop\%C3\%B5e\%20a\%C3\%A7\%C3\%A3o\%20civil\%20contra\%20prefeito\%20de $\% 20 \mathrm{SP} \% 20$ por\%20falta\%20de\%20vagas\%20em\%20creches. Acesso em: 15 jun. 2019.

http://www.mpsp.mp.br/portal/page/portal/Nucleo_Politicas_Publicas/Producao_do_NPP/e xposi\%C3\%A7\%C3\%A3o\%20de\%20motivos\%20-

$\% 2017 \% 20$ de\%20maio\%20de\%202013.pdf. Acesso em: 15 jun. 2019.

http://www.mpsp.mp.br/portal/page/portal/Portal_da_Transparencia/Licitacoes_Contratos_ Convenios/Licitacoes_Convenios/Lista_de_convenios/Lista_de_convenios_2018/033casa_ 11052018_091521.pdf, Acesso em 06 de outubro de 2019. 
http://www.mpsp.mp.br/portal/page/portal/Saude_Publica/hd_sp_tct/termo\%20de\%20coop era\%C3\%A7\%C3\%A3o\%20t\%C3\%A9cnica\%202016\%20-\%20TJ-MP-DF\%20(003).pdf. Acesso em 03 de outubro de 2019.

http://www.portalsme.prefeitura.sp.gov.br/Documentos/demanda/ALUNOS_DEMANDA_ DISTRITO-DOM01112013.pdf. Acesso em 03 de outubro de 2019.

https://cidades.ibge.gov.br/?coduf=35. Acesso em 09 de janeiro de 2019.

https://dp-sp.jusbrasil.com.br/noticias/100025967/defensoria-publica-de-sp-e-tribunal-dejustica-de-sp-celebram-parceria-para-ampliar-servico-de-conciliacao-de-conflitos-noestado. Acesso 03 de outubro de 2019.

https://dp-sp.jusbrasil.com.br/noticias/2690753/defensoria-publica-e-ministerio-publicocelebram-acordo-com-sptrans-que-facilita-concessao-de-bilhete-unico-especial-a-pessoascom-deficiencia. Acesso em 03 de maio de 2019.

https://educador.brasilescola.uol.com.br/politica-educacional/plano-nacional-educacaopne.htm. Acesso em 03 de outubro de 2019.

https://g1.globo.com/sp/sao-paulo/noticia/2019/04/01/cerca-de-60-mil-alunos-estudam-emescolas-de-lata-em-sao-paulo.ghtml. Acesso em 17 de fev. de 2019.

https://www.anadep.org.br/wtksite/downloads/iv-diagnostico-da-defensoria-publica-nobrasil.pdf. Acesso em 18 de fev. de 2019.

https://www.dizerodireito.com.br/2016/08/defensor-publico-geral-que-nao-atende.html, Acesso em 19 de abril de 2019.

https://www.premioinnovare.com.br/proposta/acordo-termo-de-ajustamento-de-condutacriando-novas-regras-mais-rapidas-justas-e-beneficas-para-concessao-e-renovacao-dobilhete-unico-especial-que-confere-gratuidade-no-transporte-publico-para-os-deficientesfisicos-e-mentais/print, acesso em 05 de setembro de 2019. 
https://www.tce.sp.gov.br/6524-tcesp-e-defensoria-publica-firmam-termo-cooperacaotecnica-e-operacional. Acesso em 06 de outubro de 2019.

https://www.tjsp.jus.br/Noticias/Noticia?codigoNoticia=56607., Acesso 03 de outubro de 2019;

https://www.valor.com.br/politica/5494921/acesso-ao-judiciario-nem-sempre-e-sinonimode-acesso-justica. Acesso em 06 de fevereiro de 2019.

https://zeroaseis.org.br/o-instituto/primeira-infancia/. Acesso em 06 de fevereiro de 2019.

http://mecsrv04.mec.gov.br/sef/fundef/funf.shtm, Acesso em 10.06.2018.

http://labedu.org.br/documentario-aborda-a-importancia-do-direito-a-educacao-infantil/ http://acaoeducativa.org.br/ - Documentário "Direito à Educação Infantil", produzido pelo advogado Dr. Rubens Naves.

<https://www.youtube.com/watch?v=jaaUCJ7J4EY> (Vídeo disponível no YouTube para explicar aos usuários o procedimento de atendimento na Defensoria do pedido de vagas em creche). 